\title{
EL CASTILLO DE BENIFALLIM, ALICANTE: UNA APROXIMACIÓN DESDE LA ARQUEOLOGÍA ${ }^{1}$

\author{
THE CASTLE OF BENIFALLIM, ALICANTE: \\ AN INITIAL INTERPRETATION FROM AN ARCHAEOLOGICAL POINT OF VIEW
}

DÉBORA MARCELA KISS

\section{INTRODUCCIÓN}

En las faldas de la sierra del Rontonar, a $850 \mathrm{~m}$ sobre el nivel del mar, en el sector occidental de la Sierra de Aitana y a unos $200 \mathrm{~m}$ al este del pueblo de Benifallim, emerge una formación de calizas arenosas de gran potencia. Semejante a una espina dorsal, dibuja una línea en dirección noreste-sureste que presenta, a lo largo de todo su recorrido, una única discontinuidad, fracturándose y desplazándose para continuar, en paralelo, unos metros más adelante. Es allí donde destaca la silueta de una torre de planta rectangular, montada literalmente sobre uno de los extremos del cordón montañoso, que domina visualmente todo el valle. A sus pies, tres muros cierran el espacio, formando un reducido recinto, de unos $280 \mathrm{~m}^{2}$.

Conocido como Castillo de Benifallim, este pequeño conjunto emplazado en la comarca de L'Alcoià, provincia de Alicante (Fig. 1), ha sido catalogado

\footnotetext{
1. Este artículo es una síntesis adaptada para su publicación del Trabajo de Investigación Tutelado por la Dra. Sonia Gutiérrez Lloret, realizado dentro del marco del Master Oficial en Arqueología Profesional dictado por la Universidad de Alicante curso 2008 - 2009. Los objetivos de este estudio eran, además de la aplicación de los conocimientos impartidos durante el mencionado curso, la complementación y profundización de las vías de análisis planteadas en el apartado de Estudios Previos de un Plan Director de Restauración del Castillo de Benifallim, realizado en colaboración con el arquitecto Ricardo Sanz Bravo y tutelado por los doctores Lauro Olmo Enciso y Javier Rivera, trabajo final obligatorio para la promoción del Master de Restauración y Conservación del Patrimonio dictado por la Universidad de Alcalá de Henares, curso 2007.

Queremos agradecer a los evaluadores anónimos de la revista Lucentum por sus oportunas observaciones y propuestas, a la Dra. Sonia Gutiérrez Lloret y al Dr. Ignacio Grau Mira por su continuo apoyo y orientación y a Jordi López Lillo, a Hernán Arredondo Conte y a Rocío Arredondo por la colaboración y ayuda prestadas que hicieron posible la redacción del presente artículo.
}

como BIC (declaración genérica) y registrado en el Inventario de Yacimientos Arqueológicos y Paleontológicos y en el de Bienes Inmuebles de la Comunidad Valenciana. No hay trabajos publicados dedicados específicamente al castillo, sólo algunas referencias de tipo descriptivo en catálogos y estudios regionales adjudicándole, la mayoría de los autores, una cronología medieval cristiana y un posible origen como torre de alquería musulmana (Fig. 2).

Tampoco ha sido objeto de excavaciones arqueológicas y los materiales detectados en prospecciones realizadas en la década de los años 80 son sumamente heterogéneos, destacando en el conjunto, por su clara adscripción a época medieval, un trozo de cerámica bizcochada pintada en manganeso con un motivo de bandas paralelas, datada en el período comprendido entre el primer tercio del siglo XIV y finales del mismo (Navarro Poveda, 1990, 184-185). En el año 2003, una nueva exploración realizada en los bancales situados al sur del recinto del castillo ha permitido localizar restos de una estructura y la recogida de muestras de material cerámico y lítico de la Edad del Bronce ${ }^{2}$ y más recientemente, durante nuestras tareas de registro, el hallazgo de un trozo cerámico inserto en la masa de uno de los muros del recinto, vuelve a remitirnos a época medieval. Reconocido, por el tipo de pasta, como perteneciente a un cántaro típico de las producciones de Paterna, posee un tipo de decoración que lo ubica en un arco cronológico amplio (desde finales de XIII a segunda mitad del XV), pues no contamos con bordes que nos permitan afinar su cronología ${ }^{3}$ (Fig. 3), si bien asegura la factura post-islámica del recinto.

2. Resultados de la prospección. Bronce. Castillo de Benifallim. -314 realizada por Francisco Javier Molina Hernández, expediente facilitado por el Museu Arqueològic Municipal Camil Visedo d'Alcoi.

3. Agradecemos el aporte del arqueólogo José Luis Menéndez en la identificación de la pieza y sus observaciones acerca de la importancia, en este caso, de los bordes a la hora de afinar la cronología. Cántaros de pasta y decoración similar 


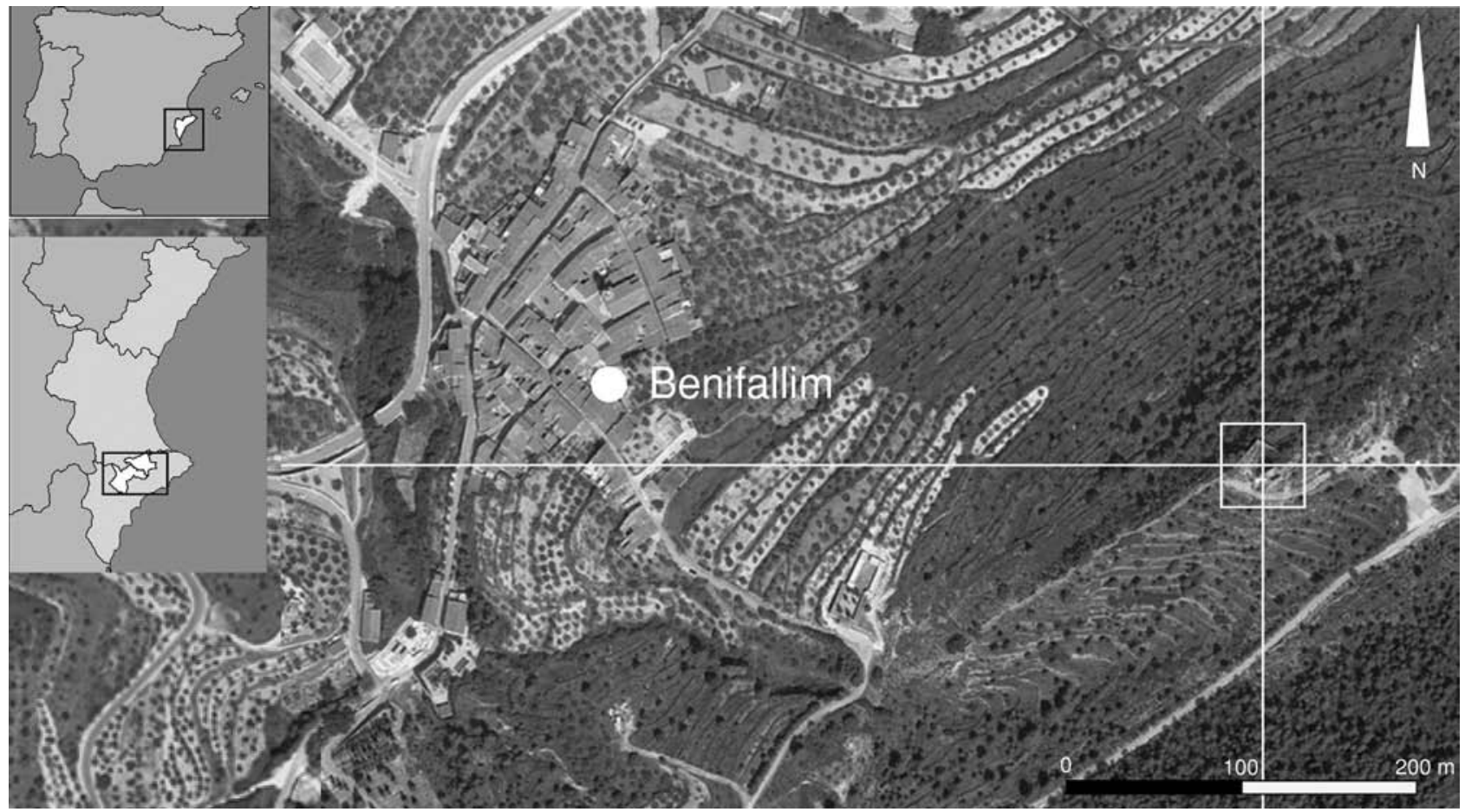

Figura 1: Localización del Castillo de Benifallim. Ortofoto en la que se aprecia su ubicación en relación al pueblo, (Fuente: Visor Web de la Conselleria de Medi Ambient, Aigua, Urbanisme i Habitatge).

Las menciones documentales con que contamos en esta etapa de nuestra investigación son escasas y provienen de fuentes cristianas de la época de la conquista, donde Benifallim es citado en cuatro ocasiones. En las dos primeras, de 1248 y provenientes de los libros de reparto ${ }^{4}$, es identificado como alquería, haciéndose referencia a la existencia de una torre que no podemos relacionar con certeza con el castillo objeto de este estudio ${ }^{5}$ (Ferrando i Francés, 1998, 179). La tercera, de 1258, es una donación asentada en los registros de cancillería donde, se menciona una "fortalicia"

con borde apuntado hallados en niveles inferiores durante la excavación del yacimiento de la Pobla de Ifach en Calpe, Alicante, por él dirigida, están fechados a finales del siglo XIII primera mitad del siglo XIV, mientras que ejemplares vinculados a bordes abocinados, comunes en las piezas encontradas en la iglesia de Santa María de Alicante, han sido fechados en la segunda mitad del siglo XV.

4. "A Eixemen Lópeç de Foces, dotze jovades de terra en el terme de le alqueries anomenades Raval i Binahalim, que estan en el terme de Penàguila. 9 d'agost...", Llibre del Repartiment de València. Reg. II. Folio 12. No 1985. Pennaguila citado en Llibre del Repartiment de Valencia. Ed. A. Ferrando i Francés

5. "A Blas Péreç d'Azlor, la torre anomenada d'Avinfierro, amb dotze jovades de terra en els termes de les alqueríes que es diuen Raval i Binahalim, que estan en el terme de Penàguila”, Llibre del Repartiment de València. Reg. II. Folio 12. No 1986. Pennaguila citado en Llibre del Repartiment de Valencia. Ed. A. Ferrando i Francés
(Guichard, 1982, 30) ${ }^{6}$ y la cuarta es la Carta Puebla de Benifallim ${ }^{7}$, fechada en 1316 (Guinot, 1991, 478-479).

Este número restringido de datos arqueológicos y documentales, lejos de convertirse en un escollo, ha sido la principal motivación para la realización de este trabajo. Deseamos, por tanto, aportar nuestro grano de arena al conocimiento de un yacimiento cuya relativa fragilidad se acentúa dadas las características de su emplazamiento, tanto geográficas, por pertenecer a un pequeño municipio de escasos 150 habitantes y limitados recursos para afrontar su mantenimiento, como físicas, al estar cimentado sobre un tipo de caliza con tendencia a la fractura que ha sufrido nuevos desprendimientos recientemente, a pesar de haber sido sometida a tareas de consolidación de urgencia en el año $2007^{8}$.

6. Archivo de la Corona de Aragón, Reg. de Cancillería, $N^{\circ} 10$, Fol. 61 V. Documento de donación de la alquería de Benifallim, a 28 de abril de 1258. (parece existir un problema en la identificación de la regesta del documento que amablemente nos ha indicado Leonardo Soler, a quien agradecemos, quedando pendiente la compulsa directa del mismo).

7. Carta Puebla 20-11-1316. Copía del s. XV, Real Cancillería, Reg. 614, Fol. 246. Bernat de Cruilles, señor de Penàguila otorga la carta puebla para treinta pobladores del lugar de Benifallim, término de Penàguila, citada por E. Guinot, Collecció documental. Les cartes de poblament medievals valencianes.

8. Esta actuación fue llevada a cabo por la Conselleria de Cultura a través de la Dirección General de Patrimonio Cultural Valenciano y Museos. 


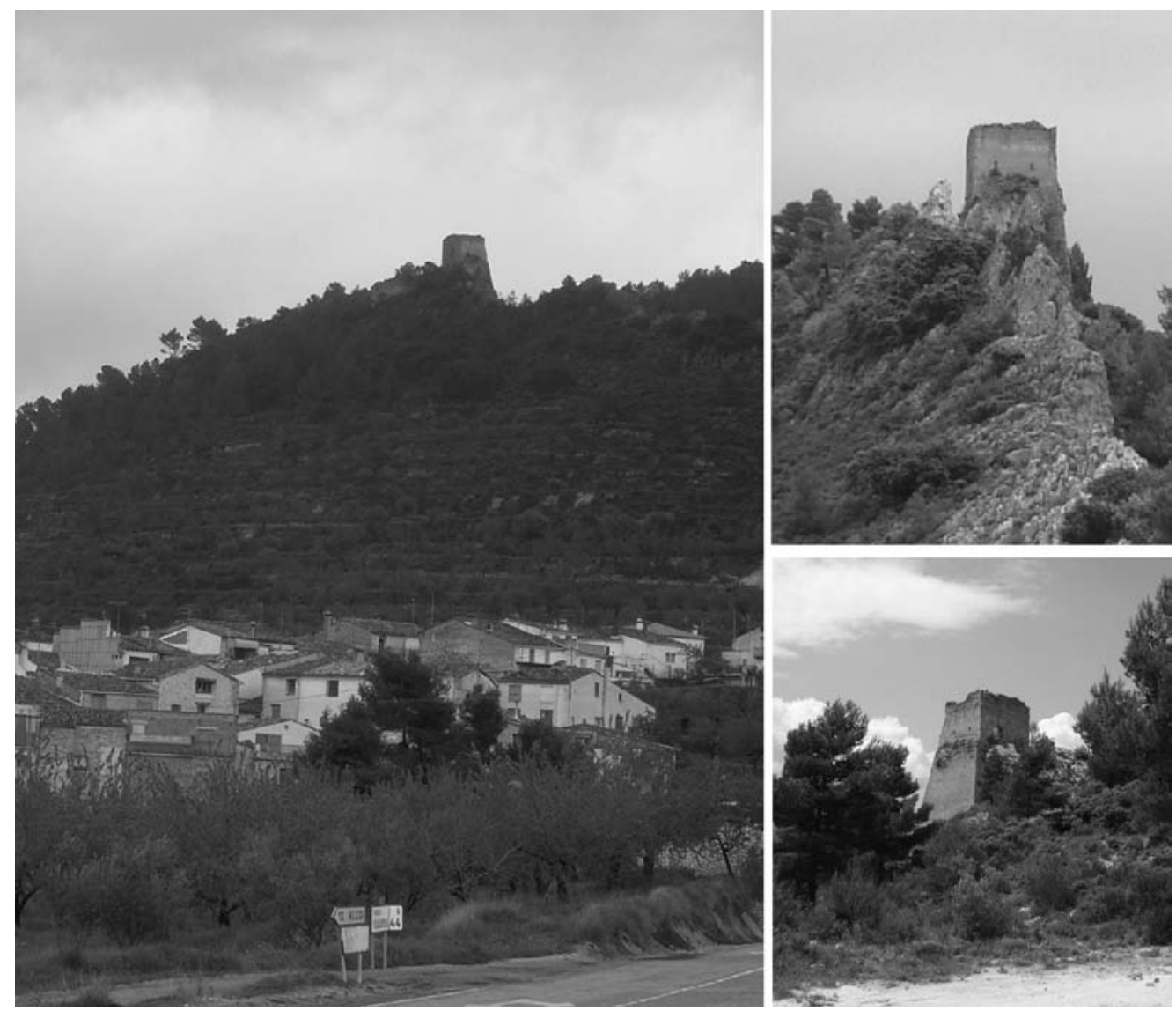

Figura 2: Imágenes del Castillo de Benifallim y de su entorno de implantación.

Por lo tanto, hemos fijado como objetivo primordial la lectura y registro del monumento, aplicando metodología arqueológica. Mediante la lectura estratigráfica de paramentos, no sólo analizaremos las posibles etapas de construcción y los cambios sufridos a lo largo del tiempo, sino que detectaremos facturas, sistemas de construcción y elementos singulares, para conocer el objeto arquitectónico en todas sus facetas: ejecución, remodelaciones, reutilizaciones y abandono.

Llegados a este punto, el análisis trascenderá los límites del edificio para centrarse en el paisaje, intentando acercarnos, en una mirada transversal, a la observación y compresión de los rasgos formales que caracterizan y los principios que estructuran las relaciones que se establecen entre ambos. En primer lugar, realizaremos un brevísimo recorrido por la evolución histórica de la comarca, con la intención de identificar las distintas lecturas espaciales en los patrones de asentamiento en las diferentes épocas. A continuación, ubicaremos los elementos componentes de la trama: poblados, vías de comunicación y sistema defensivo, para posibilitar, por su intermedio, la detección de determinadas constantes en la formación de los paisajes que nos permitan ubicar al yacimiento, al menos de manera aproximada, dentro de un marco cronológico. Es nuestra intención plantear una serie de cuestiones que se desarrollarán de manera más extensa en una investigación actualmente en proceso de elaboración, que busca la elaboración de una metodología para aplicar al estudio de las fortificaciones medievales de la comarca.

\section{EL CASTILLO COMO OBJETO ARQUITECTÓNICO}

Forma, construcción, función y entorno determinan y condicionan la génesis y las transformaciones que un objeto arquitectónico sufrirá durante su existencia, otorgándole las características que lo hacen único e identificable y que le posibilitan responder formal, tipológica y técnicamente a los planteamientos estéticos, necesidades espaciales y recursos técnicos de la época en la que es concebido (Caballero Zoreda y Latorre González-Moro; 1995, 9-11).

Al abordar el conocimiento de un edificio desde la arqueología recorreremos el camino inverso: identificando cada parte, interpretaremos su función y la ubicaremos temporal y espacialmente, para poder reconstruir el contexto en que pudo haber sido incorporada a la construcción. Por lo tanto, para poder obtener la máxima información del espacio construido, es necesario conocer en detalle cada una de las unidades que lo componen a fin de comprender las relaciones que se plantean entre ellas, observando los distintos elementos para desentrañar la lógica constructiva y estructural que los vincula. 

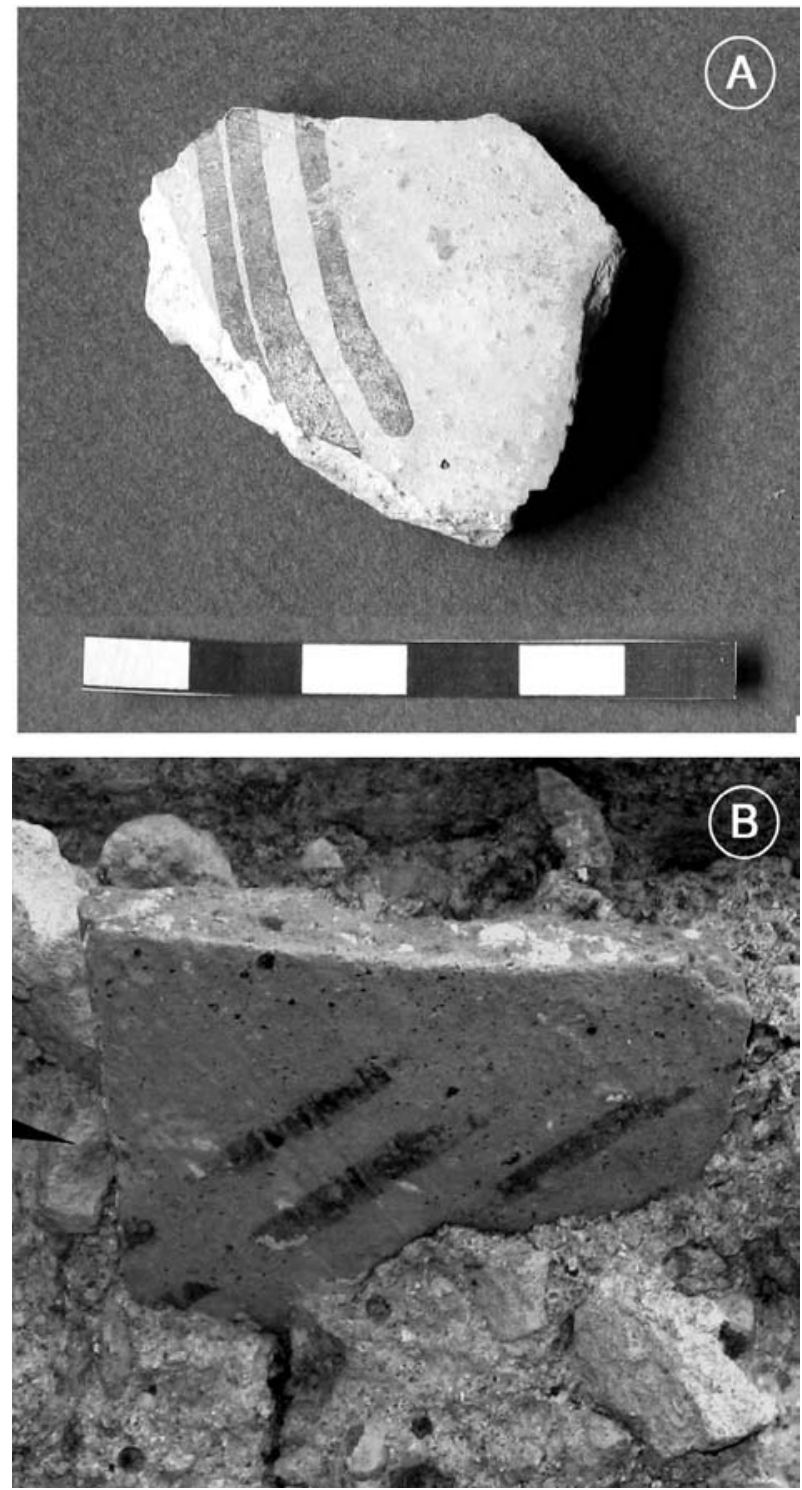

Figura 3: Foto A: Fragmento de cerámica medieval recolectada en la prospección de los años '80. Colección Museu Arqueològic Municipal Camil Visedo d'Alcoi'. Foto B: Fragmento cerámico, posiblemente de cántaro de Paterna, detectado en el muro noreste del recinto.

Como adelantamos en la introducción, el castillo de Benifallim es un conjunto formado por dos elementos, una torre y un recinto (Fig. 4$)^{9}$.

La torre (Fig. 5), ubicada sobre una cresta, se eleva a unos $10 \mathrm{~m}$ sobre el nivel del patio. Es una estructura rectangular, de $7,20 \mathrm{~m} \times 8,50 \mathrm{~m}$, que conserva sus muros perimetrales hasta una altura promedio de $6,50 \mathrm{~m}$ y el arranque de la bóveda del techo, y en la que podemos distinguir una fase de construcción, la obra original y dos intervenciones de consolidación: una de datación indefinida y otra realizada recientemente (julio de 2007)

9. Agradecemos al Museu Arqueològic Municipal Camil Visedo d'Alcoi, y en particular a su director J. M. Segura Martí, el habernos facilitado estos materiales para su estudio.
La técnica constructiva empleada es conocida como tapial (en árabe tâbiya) y consiste en el moldeado del muro mediante el uso de un encofrado de tablas de madera unidas por travesaños verticales y horizontales formando un cajón rectangular. En su interior se vierte la mezcla en tongadas, se apisona para eliminar los espacios vacíos y una vez completo, se espera a que fragüe para poder desplazar el molde y continuar con la siguiente caja o tapia sin peligro de que se produzcan deformaciones. Debido a la forma en que se desarrolla el proceso, los travesaños inferiores, cuando son de madera, no pueden quitarse pues quedan aprisionados entre hiladas, aprovechándose como apoyo de los andamios hasta la finalización de la obra, momento en el que se cortan los salientes, quedando el resto perdido en la masa del muro.

Los materiales que componen el tapial son variados pues suelen provenir del entorno inmediato de la obra. Los hay de tierra o de mortero, en los que se incluyen agregados gruesos, tales como grava, fragmentos de cerámica o piedras.

La fábrica de la torre está construida en tapial de tipo mixto (Font e Hidalgo, 1991,33-34; Lopez Elum, 2002 (v2), 159), que se caracteriza por el refuerzo de ambas caras por medio de mampuestos ${ }^{10}$. En este caso, se trata de una mezcla de cal con arcilla y piedras de distintos tamaños, las más pequeñas se hallan incluidas en la masa y las de mayor calibre, ordenadas dentro del encofrado, colocadas sus caras más planas contra la superficie del molde, con el fin de otorgarle al muro mayor resistencia al impacto. Debido a ello, en las zonas donde se ha perdido el revoco, puede confundirse con una fábrica de mampostería, percibiéndose sólo a corta distancia las marcas propias del sistema: los huecos a distancias regulares de los travesaños, (algunos conservando incluso restos de los mismos), coincidentes con las líneas horizontales que marcan los límites entre tapias (Fig. 6).

Utilizado de manera general en las fortificaciones a partir del S.IX ${ }^{11}$, la continuidad del empleo de este sistema constructivo, aún en época de conquista cristiana, se explica por la relativa simplicidad de la técnica (en comparación con la mampostería o la sillería que

10. Esta técnica particular que se caracteriza por el refuerzo de ambas caras por medio de mampuestos de piedra o ladrillos también es conocida con el nombre de "tapial valenciano", aunque algunos autores reserven esta denominación únicamente para aquellos casos donde la doble hoja se halla ejecutada en ladrillo y costra (Galarza Tortajada, 2003, 398) y con el nombre de "tapia real "(Aymat Escalada, 2007,19).

11. Según R. Azuar Ruiz $(2005 ; 158)$ el plan de fundación y refortificación de ciudades llevado a cabo por el Emir Muhammad marca los inicios de la utilización de la técnica del tapial, de uso corriente en construcciones urbanas, en las fortificaciones. Algunos autores, como por ejemplo F. Valdés Fernández $(1992 ; 135)$, sugieren que la utilización del tapial en la arquitectura defensiva se generaliza a partir del siglo XII. 


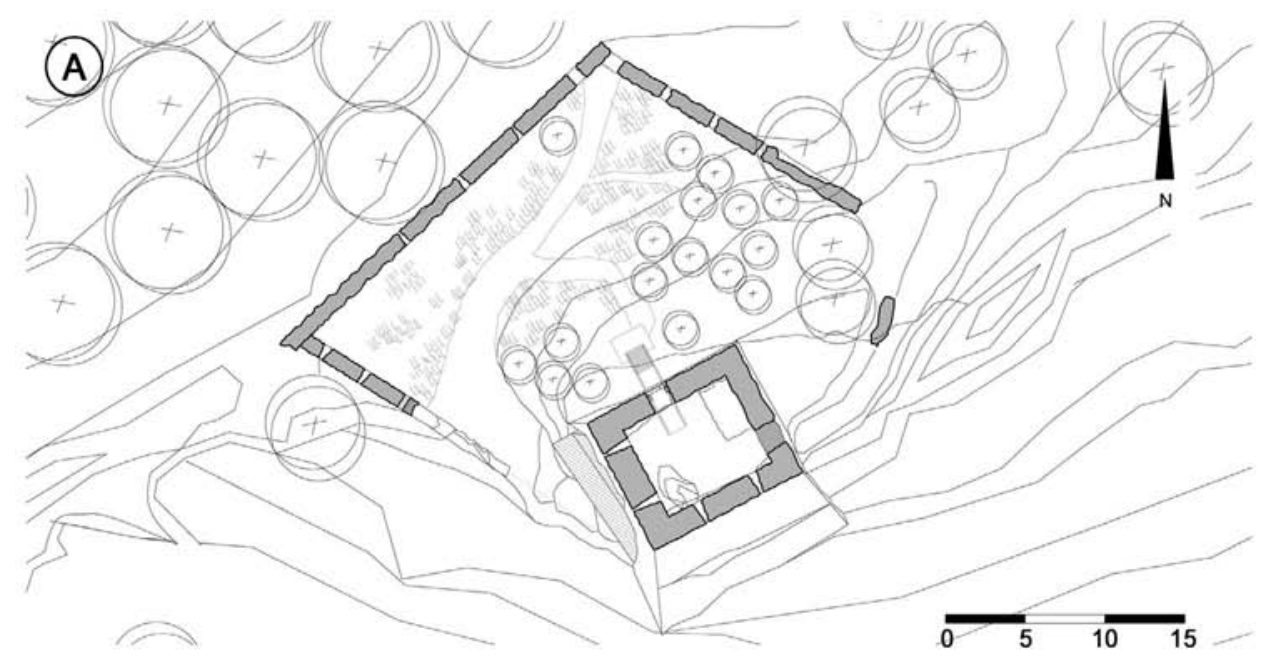

(B)

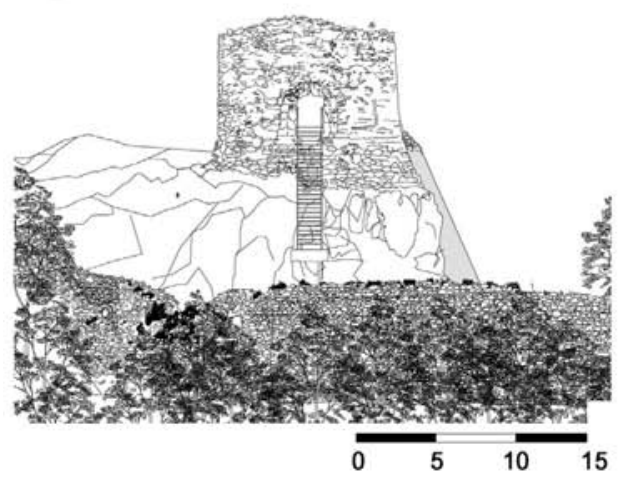

(D)

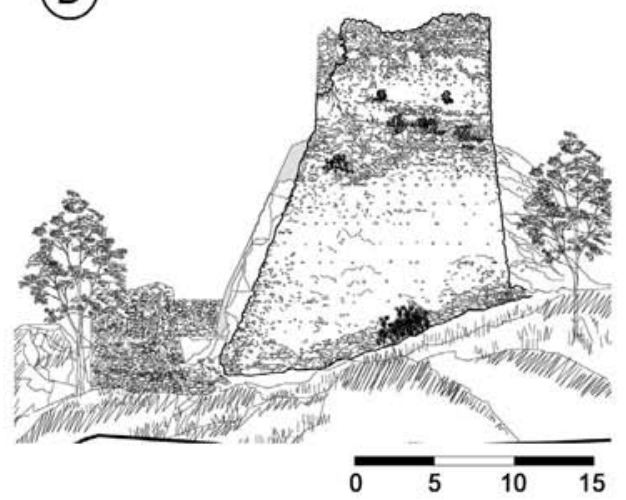

(C)

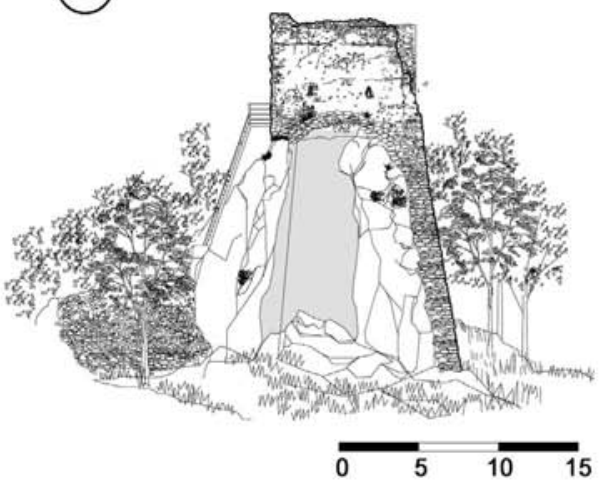

(E)

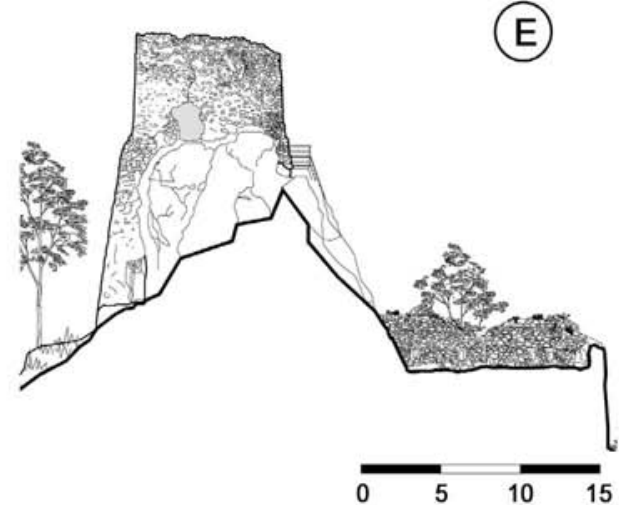

Figura 4: Castillo de Benifallim, estado actual. A: Planta. B: Alzado noroeste. C: Alzado suroeste. D: Alzado sureste, E: Alzado noreste.

exigían una mayor especialización y complejidad en el proceso de producción), la economía que significaba la posibilidad de reaprovechar los encofrados, la rapidez de ejecución, la fácil obtención de los materiales (en gran parte extraídos del entorno inmediato) y la existencia de mano de obra barata y especializada. Esta permanencia dificulta aún más distinguir la procedencia de las fábricas, lo que ha generado la elaboración de una serie de propuestas que relacionan las dimensiones de los encofrados, detectables por las marcas derivadas del proceso de fabricación, con las unidades de medida empleadas por cristianos o musulmanes. 


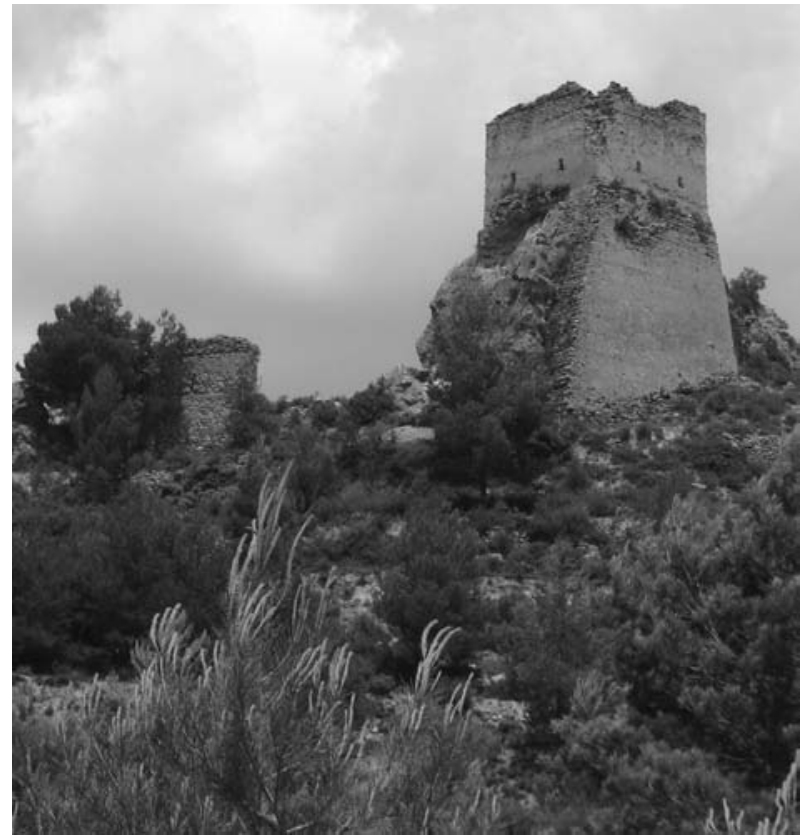

Figura 5: Imágen del castillo desde su fachada suroeste.

Sin embargo, las seriaciones no dan, a nuestra opinión, resultados concluyentes ${ }^{12}$. Podemos en cambio afirmar que, a partir del registro detallado de la modulación de las tapias de las torres de alquería de la huerta de valencia realizado por P. Rodríguez Navarro (2008, 284), y su comparación con las medidas obtenidas de las torres de Torre de les Maçanes y Almudaina (ambas ubicadas en zonas cercanas e identificadas como torres de alquería), se detecta una tendencia en las medidas de las mismas, que se colocan en un rango que va de los 0,82 $\mathrm{m}$ a los 0,87 $\mathrm{m}$ de altura, y que coinciden con el módulo registrado en la torre del castillo de Benifallim

12. Para intentar encontrar una relación entre las medidas de las tapias y la procedencia de las fábricas, P. López Elum (2002, 161-169)considera los siguientes codos: el geométrico o común $(0,417 \mathrm{~m})$ el mayor o morisco $(0,743 \mathrm{~m})$, el mediano o raššaší $(0,557 \mathrm{~m})$ y el codo real $(0,547 \mathrm{~m})$, obteniendo a partir del cálculo de una vara ( 2 codos) las diferentes medidas. Los resultados dan una seriación de medidas a partir del codo árabe de $74 \mathrm{~cm}, 84 \mathrm{~cm}, 94 \mathrm{~cm}$ y $112 \mathrm{~cm}$ con fluctuaciones de $2 \mathrm{~cm}$ según el tipo utilizado Para las fábricas cristianas toma como base la medida del palmo valenciano $(0,2275 \mathrm{~cm})$, la vara equivaldría a 4 palmos, obteniendo valores de $91 \mathrm{~cm}$ (1 vara) y $114 \mathrm{~cm}$ para las fábricas cristianas (5 palmos). A partir de la comparación de ambos sistemas de medidas, el andalusí y el cristiano, el autor concluye que los encofrados que oscilan entre 0,80 y 0,94 son musulmanes. Como podemos observar, las seriaciones se superponen y las diferencias entre las medidas que indican una y otra procedencia son muy pequeñas, lo que las hace difícilmente verificables en edificios muy degradados como el que estamos estudiando, donde existen variaciones dentro de una misma fábrica de varios centímetros entre hiladas, aún cuando no se detecten discontinuidades que indiquen reparaciones o diferentes etapas de construcción.

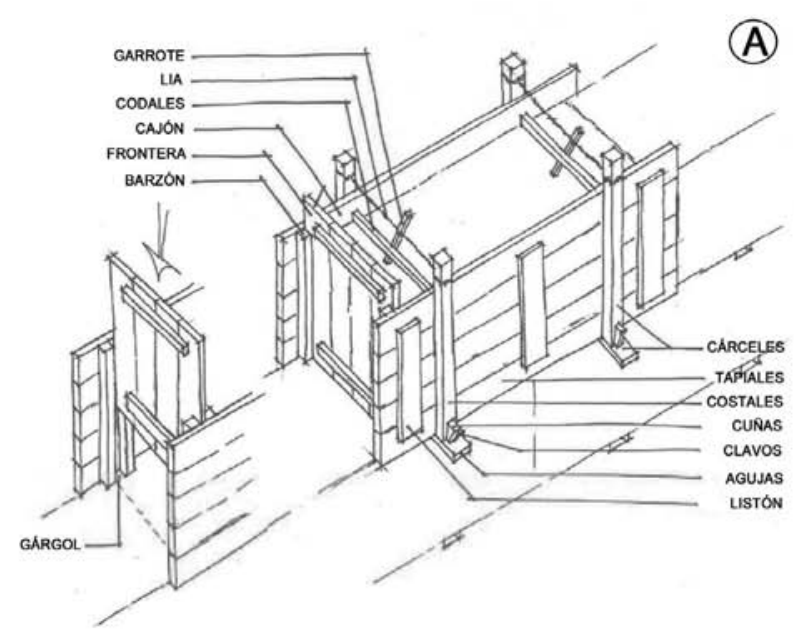

$\tan x-200$
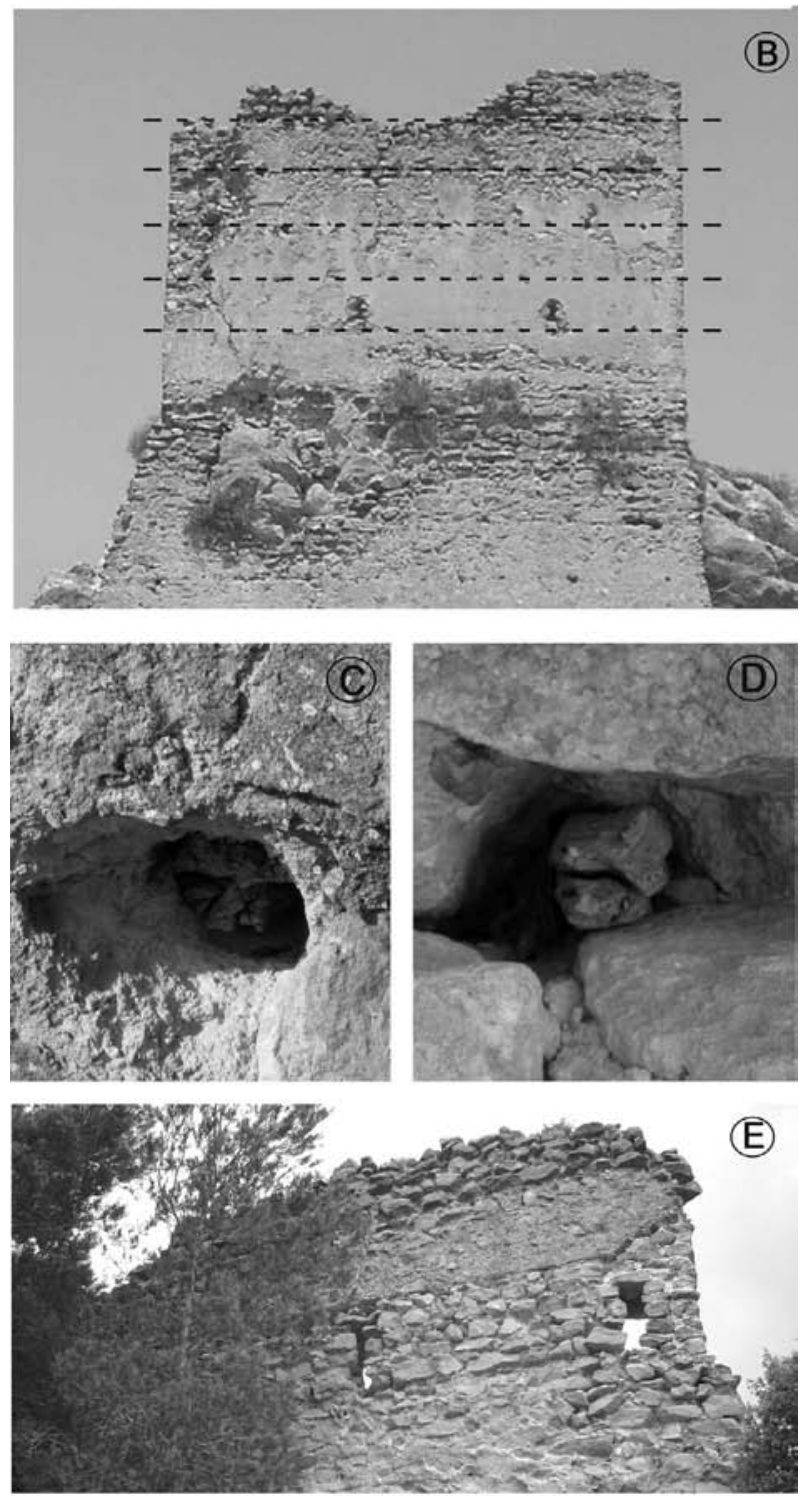

Figura 6: La técnica del tapial. A: Partes de un tapial según las improntas encontradas en las torres valencianas (Fuente: Rodriguez Navarro, 2008; 233, fig. 8,137). B: Fachada sureste de la torre señalando las líneas de las tapias. C y D: Travesaños que se conservan en el cuerpo del muro. E: Muro del recinto donde se leen muy nítidamente las líneas de tapias. 

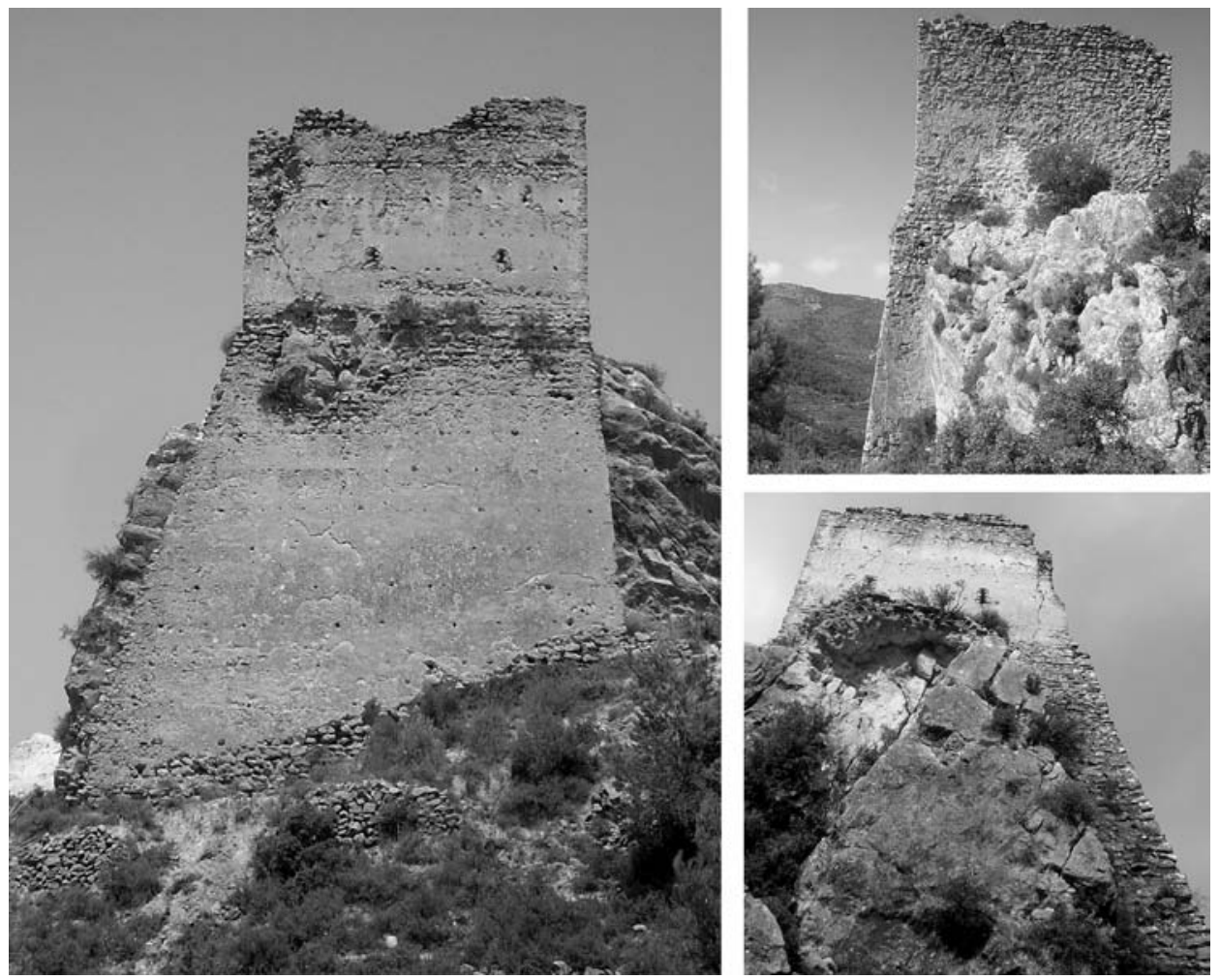

Figura 7: Imágenes del talud para complementar el apoyo del basamento. A la izquierda: fachada suroeste. A la derecha arriba, fachada noreste y abajo, fachada sureste.

de $0,85 \mathrm{~m}$. El recinto, en cambio, presenta una altura entre hiladas de $0,90 \mathrm{~m}$, lo que sugiere una posible diacronía en su construcción, hipótesis que se vería reforzada por otro conjunto de variables relacionadas a la composición y calidad de la técnica y los materiales de una y otra fábrica.

Debido a las características físicas del material, el mayor enemigo del tapial es el agua, que al penetrar en el cuerpo del mismo disgrega sus componentes, lo que obliga a adoptar determinadas soluciones para aislarlo tanto de las humedades ascendentes del suelo y de las provenientes de los agentes atmosféricos (lluvia, viento, nieve y hielo) como de las salpicaduras por rebote ${ }^{13}$.

13. La alterabilidad de la tierra ante la presencia de agua ha llevado al empleo, por parte de los constructores, de los llamados estabilizantes, que protegen de la erosión y de los aumentos de volumen. Uno de los mas utilizados es la cal, que no sólo protege las juntas entre hiladas sino que también, mezclada con la tierra, otorga resistencia e inalterabilidad al material (Font e Hidalgo, 1991,45-46). La ascensión de agua por capilaridad es muy baja en la tapia endurecida sobre todo cuando la porosidad es grande, sin embargo, su sensibilidad a las salpicaduras por rebote y a los ciclos de hielo y deshielo es muy alta. El comportamiento frente a la erosión hídrica en muros de tapial puede mejorarse ejecutando una tapia de tipo real o calicostrando el cajón (aplicando un jaharrado con mortero de cal y arena en proporción 1:3 sobre los tableros laterales del encofrado de forma que quede luego adherido a la masa apisonada e integrado en el cajón). (Aymat Escalada, 2007, 23).
En este caso, se ha resuelto levantando la torre sobre un basamento de mampuestos irregulares de piedra unidos con mortero, con una ligera inclinación formando un talud de aproximadamente 1,50 $\mathrm{m}$ de altura que, además de proteger el muro, nivela las discontinuidades del terreno y crea una superficie de apoyo regular, indispensable para el armado del encofrado. Realizado con la misma técnica de tapial, una parte importante del basamento del muro sureste apoya en un enorme talud que llega hasta la base misma de la peña (unos $10 \mathrm{~m}$ de altura), cuya construcción posiblemente esté vinculada al comportamiento de la piedra que compone la formación rocosa sobre la que apoya el edificio. Esta caliza con tendencia a disgregarse con la humedad, fisura por acción de los factores atmosféricos y de las dilataciones y contracciones debidas a los cambios de temperatura, fallas que permiten el ingreso de agua que provoca la fractura y separación de grandes trozos. La finalidad de esta estructura adicional sería, por tanto, apuntalar el lado más débil o con menor superficie de apoyo, donde la peña tiene una pendiente casi vertical. Su ejecución es contemporánea al muro que soporta, no detectándose cortes o discontinuidades que indiquen una reconstrucción por desplome de la pared original, caso contrario del refuerzo que apuntalaba la cara sureste, (actualmente oculto por las recientes obras de consolidación) y cuya fase de construcción, es claramente posterior a la torre (Fig. 7).

La adopción del basamento en talud, relativamente frecuente en torres cristianas y musulmanas, estaría 

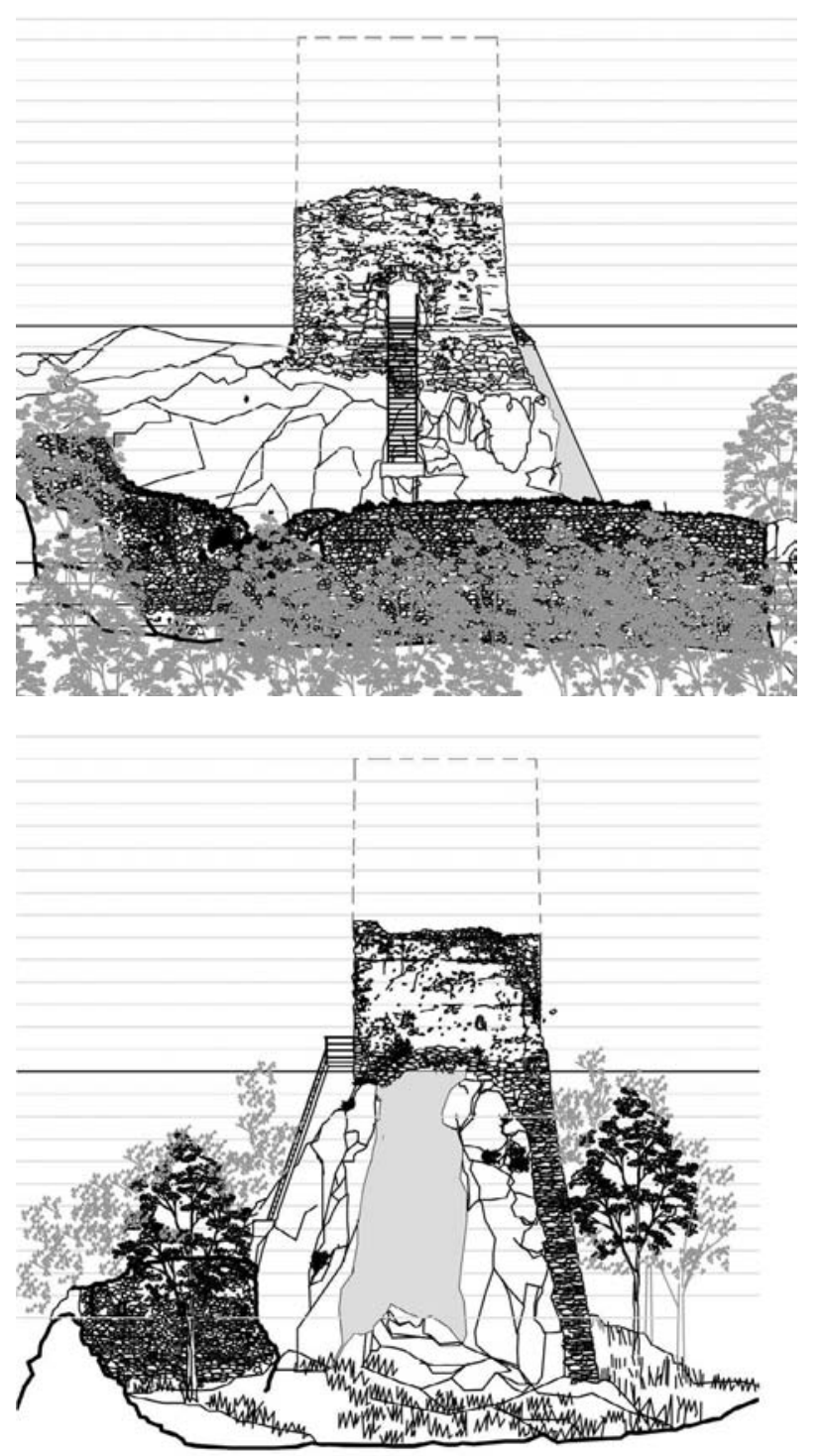

Figura 8: Hipótesis de altura total de la torre a partir de la relación proporcional 1/10. Fachada noroeste y suroeste.

relacionada con la estabilidad del terreno de fundación. Usado en suelos poco firmes, permite un mejor reparto de las cargas, optándose en cambio, cuando la resistencia del mismo lo permite, por la fundación directa, donde las paredes continúan hasta el firme y se maciza sólo la parte inferior (Rodríguez Navarro, 2008, 248-252).

Las soluciones constructivas, por lo tanto, están íntimamente relacionadas con la resolución de una serie de problemas estructurales, cuyo objetivo final consiste en lograr que las fuerzas, producto del peso propio y de los esfuerzos generados por empujes, dilataciones, asentamientos, etc., lleguen a la tierra. Las estructuras antiguas a base de muros portantes son, por su masa y composición, naturalmente resistentes, pero inestables. La estabilidad ${ }^{14}$ se logra cumpliendo

14. La estabilidad es la capacidad de los cuerpos de volver al estado de equilibrio después de haber sido desplazados de él. determinadas reglas referidas a la proporción, la unión entre los componentes y la trayectoria y tamaño de las cargas a las que se somete la estructura.

La relación entre el espesor del muro y su altura, debe alcanzar valores que eviten una excesiva esbeltez para impedir que se produzca, ante esfuerzos verticales de compresión, la curvatura por pandeo ${ }^{15}$ (De Miguel, 1998, 205-206). Los valores más adecuados rondan la proporción 1/10 (el alto igual a 10 veces el espesor), lo que nos lleva a suponer una altura total para la torre de aproximadamente unos 10 a $12 \mathrm{~m}$ de altura, en razón del espesor promedio de sus muros que ronda el 1,15 m (Fig. 8).

Los muros tienen la capacidad de resistir los esfuerzos de compresión siempre y cuando sus componentes puedan absorber las dilataciones transversales derivadas de este estado de tensión. De no ser así, estas tensiones podrían producir la disgregación del elemento poniendo en peligro su estabilidad interna. Por más resistente que sea el material que compone la fábrica, es imprescindible que sus elementos estén fuertemente engarzados y trabados. En las paredes de mampostería y sillar se resuelve evitando la continuidad de las juntas verticales y utilizando piezas pasantes, mientras que, en el tapial, se anclan las tracciones absorbiéndolas por medio de un elemento indiferenciado y continuo que actúe a modo de piel tensa, el revoco. Por lo tanto, las técnicas de enfoscado y encalado de los muros cumplen no sólo una función estética sino estructural, pues evitan la meteorización de la superficie y su consiguiente degradación y pérdida de capacidad portante (De Miguel, 1998, 203-206). El enlucido, que revestía todas sus caras interiores y exteriores y probablemente también el remate horizontal, estaba destinado a impermeabilizar, proteger y dar cohesión a la fábrica, cubriendo todas las discontinuidades e impidiendo la penetración del agua. Dentro de las zonas que aún conservan parte del revoco (alrededor de un $30 \%$ de la superficie de la torre), se detectan al menos tres capas: una muy basta, de unos $2 \mathrm{~cm}$, con bastante cal, arcilla y un árido de granulometría pequeña (gravillas o arenas gruesas); una un poco más fina $(1 \mathrm{~cm})$

En arquitectura, una estructura es estable cuando el punto donde se concentran todas las fuerzas que sobre ella actúan y que se llama centro de gravedad, se encuentra ubicado dentro del perímetro de su base.

15. La compresión es un estado de tensión en el cual las partículas del material se aprietan entre si. Un muro tiende a comprimirse cuando se le aplica una carga en la parte superior. Las cargas siempre tienden a desplazarse según las leyes de la gravedad, eligiendo entre todas las trayectorias posibles la más directa. Frente a la posibilidad de acortarse o curvarse, el muro tenderá a acortarse cuando las cargas sean relativamente pequeñas y a curvarse cuando suceda lo contrario, ante grandes cargas, Cuando se llega a determinados valores es más fácil absorber el esfuerzo curvándose que comprimiéndose, lo que llegado a cierto punto en la resistencia del material, determinará su rotura. (Salvadori y Heller, 1987, 60-61) 
de cal y arcillas, que presenta una serie de marcas diagonales en forma de espiga realizadas durante su ejecución con el objeto de dar adherencia a una tercer capa, también de cal y arcilla pero más delgada y regular $(0,5 \mathrm{a} 1 \mathrm{~cm})$, que conformaba el acabado final, $\mathrm{y}$ que debía ser remozada con cierta frecuencia mediante la aplicación de lechadas de refuerzo.

A la compresión se suman una serie de esfuerzos horizontales: la acción del viento, movimientos sísmi$\cos ^{16}$, asentamientos diferenciales, etc, y los generados por forjados y cubierta, tensiones que deben resolverse arriostrando los muros de $\operatorname{carga}^{17}$ por medio de paredes transversales, configurando una estructura de tipo cajón donde todas las partes componentes deben funcionar solidariamente. Debido a ello, la resolución de los encuentros entre fábricas es clave, por ser punto de concentración de las mayores tensiones, recurriéndose en el caso que estamos estudiando a la colocación de piedras de mayor tamaño a modo de refuerzo del ángulo y de traba del sistema.

Con respecto a la cubierta y posibles forjados, no se conservan más que restos de los arranques de una bóveda en las paredes sureste y noroeste, que funcionarían por tanto como muros de carga, y la marca de su trazado en la suroeste, que junto con la noreste funcionaban como riostra de las anteriores (Fig. 9). Para su ejecución se contó posiblemente con el auxilio de una estructura adicional tipo cimbra, ya que el uso del tapial denota el dominio de la técnica de montaje de encofrados de madera. Estaba construida en lajas de piedra colocadas en hiladas sucesivas unidas con argamasa, avanzando conforme seguían la curvatura y trabando el sistema con la hilada central. Los empujes horizontales generados por las bóvedas son directamente

16. Con respecto a los sismos, queremos aclarar que el terreno, ante el paso de las ondas sísmicas, no se mueve exclusivamente en dirección horizontal o vertical sino que desarrolla un movimiento complejo y repetido en todas direcciones. Cerca del epicentro se perciben intensas sacudidas tanto verticales como horizontales pero en los lugares alejados, el movimiento predominante es el horizontal. Para ser gráficos, los edificios, sobre todo los que presentan un desarrollo en altura, oscilan en un movimiento de tipo péndulo invertido, empotrado en la parte inferior y con los mayores desplazamientos en la superior. Estos empujes son los mas desfavorables desde el punto de vista estructural, generando fuerzas laterales que dependen de la masa y la altura del edificio (a mayor peso en la parte superior mayor fuerza lateral se genera) (centro nacional de prevención de desastres. México, en línea http://www.cenapred.gob.mx/es/ PreguntasFrecuentes/faqpopo3.html\#preg2) y que requieren la toma de determinadas medidas de refuerzo, como las aqui especificadas, para permitir la correcta transmisión de las fuerzas de la cubierta por medio de los elementos de soporte a los cimientos.

17. Se denomina muro de carga o muro portante a las paredes de una edificación que poseen función estructural, es decir, que soportan otros elementos del edificio tales como arcos, bóvedas, vigas o viguetas de forjados o de la cubierta.
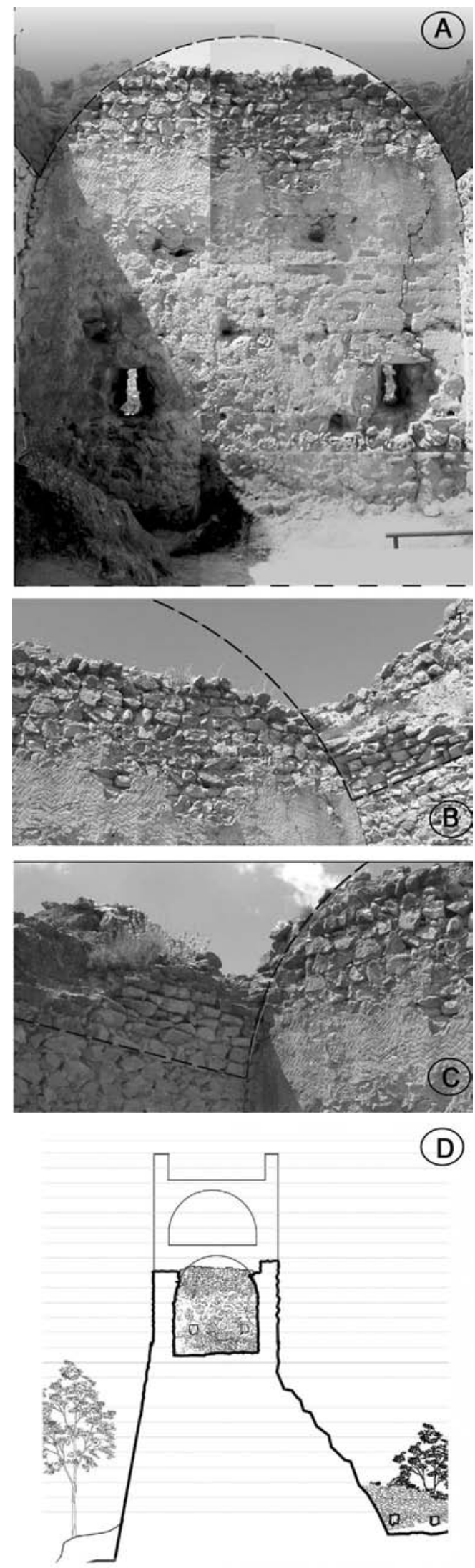

Figura 9: Restos de la bóveda. A: Bosquejo del trazado de la bóveda sobre montaje fotográfico de la cara interior del muro suroeste. B y C: Arranque de la bóveda en muros noreste y sureste con proyección de su posible curvatura. D: Sección con propuesta hipotética de la bóveda y del nivel superior. 

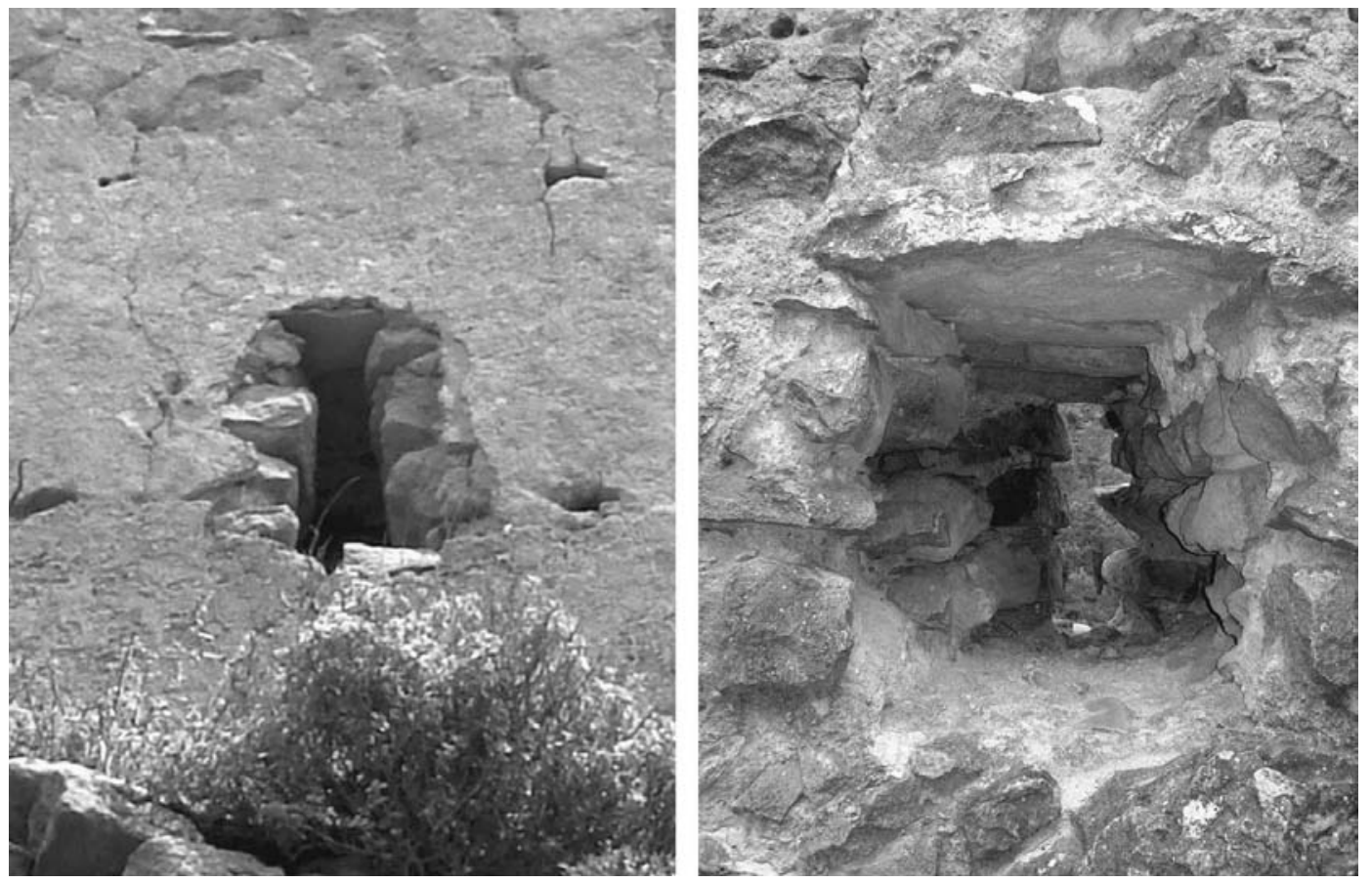

Figura 10: Saeteras. De izquierda a derecha. Fotografía de la cara exterior de una de las saeteras de la torre, imagen de la misma saetera desde la cara interior donde puede observarse el abocinamiento característico para permitir posicionarse al tirador y la resolución del dintel con la colocación de una pieza de piedra mayor y ligeramente escuadrada.

proporcionales a las cargas que soportan y al cuadrado de la luz que cubren e inversamente proporcionales a la altura del arco, por lo tanto, es posible reducirlas con la ejecución de un arco lo más liviano y alto posible, siendo la forma más estable la correspondiente al arco de medio punto, donde la medida del radio es igual a la mitad de la luz a cubrir (Salvadori y Heller, $1987,124)$, proporción que se cumple en nuestro caso (el radio es de $2,30 \mathrm{~m}$ y la luz libre es de $4,90 \mathrm{~m}$ ). A partir de la reconstrucción de su trazado y suponiendo un espesor de unos $0,60 \mathrm{~m}$ a $0,80 \mathrm{~m}$ más el relleno de regularización, podríamos ubicar el nivel del suelo superior a una altura de $6,50 \mathrm{~m}$ (medidos a partir del umbral de acceso) lo que indica la posibilidad de la existencia de una entreplanta antes de la cubierta de unos 3,20 m de altura libre. Ciertas discontinuidades en la línea de arranque de la bóveda situadas a una distancia de unos $0,90 \mathrm{~m}$ del muro noreste y coincidentes con la aparición de una especie de ménsulas y la presencia de mechinales de diferente tamaño y posición que los generados por el sistema de encofrados, nos indicarían la posición de la escalera de acceso a esta planta superior, con seguridad de madera, pues no hay evidencias de su construcción en obra, detectándose además en el ángulo entre los muros noreste y noroeste, una especie de estructura de planta rectangular de 1,50 por $2,90 \mathrm{~m}$, que podría servir de apoyo o de arranque a la misma.

La bóveda tiene continuidad con el muro de tapial en el arranque, luego la pared reduce su espesor unos $0,30 \mathrm{~m}$, porque una vez absorbidos los esfuerzos de la bóveda y a medida que el muro se eleva en altura, las cargas se reducen y pueden resolverse con grosores menores, lo que redunda en un ahorro importante de material y tiempo de ejecución.

Dada la forma y medida de las aberturas queda evidenciado el carácter defensivo de la construcción. Resueltas con la colocación de una piedra grande y plana, sin escuadrar, a modo de dintel en la parte superior, sus medidas promedio son $0,20 \mathrm{~m}$ de ancho por $0,60 \mathrm{~m}$ de alto en la cara exterior del muro y 0,50 $\mathrm{m}$ por $0,60 \mathrm{~m}$ en la cara interior, presentando la forma abocinada característica de las saeteras, donde la amplitud de la medida interior permite acomodarse al tirador que es protegido, a su vez, por la estrechez de la medida exterior. Su posición en las fachadas estaría relacionada con necesidad de defensa de los frentes mas expuestos, lo que explica su ausencia en la cara de la torre que da al recinto, ya que contaba con la protección extra que desde éste se ejercía y/o la posible existencia de algún medio adicional de resguardo ubicado en las plantas superiores (Fig. 10).

Las fortalezas, desde las más sofisticadas a las más sencillas, responden técnica y formalmente a una necesidad de resguardarse de ataques externos, y su presencia como elemento estratégico cambia, en cierta manera, la forma plantear las contiendas, pues conduce frecuentemente al abandono del campo de batalla para concentrarse en el asedio de estos puntos fuertes (Varela Agüi, 2002, 102; García Fitz, 2005, 171179). Es por ello que la estrategia de defensa de las torres medievales consistía principalmente en impedir que el enemigo pudiera aproximarse, manteniendo un perímetro de seguridad mediante distintos medios defensivos. 

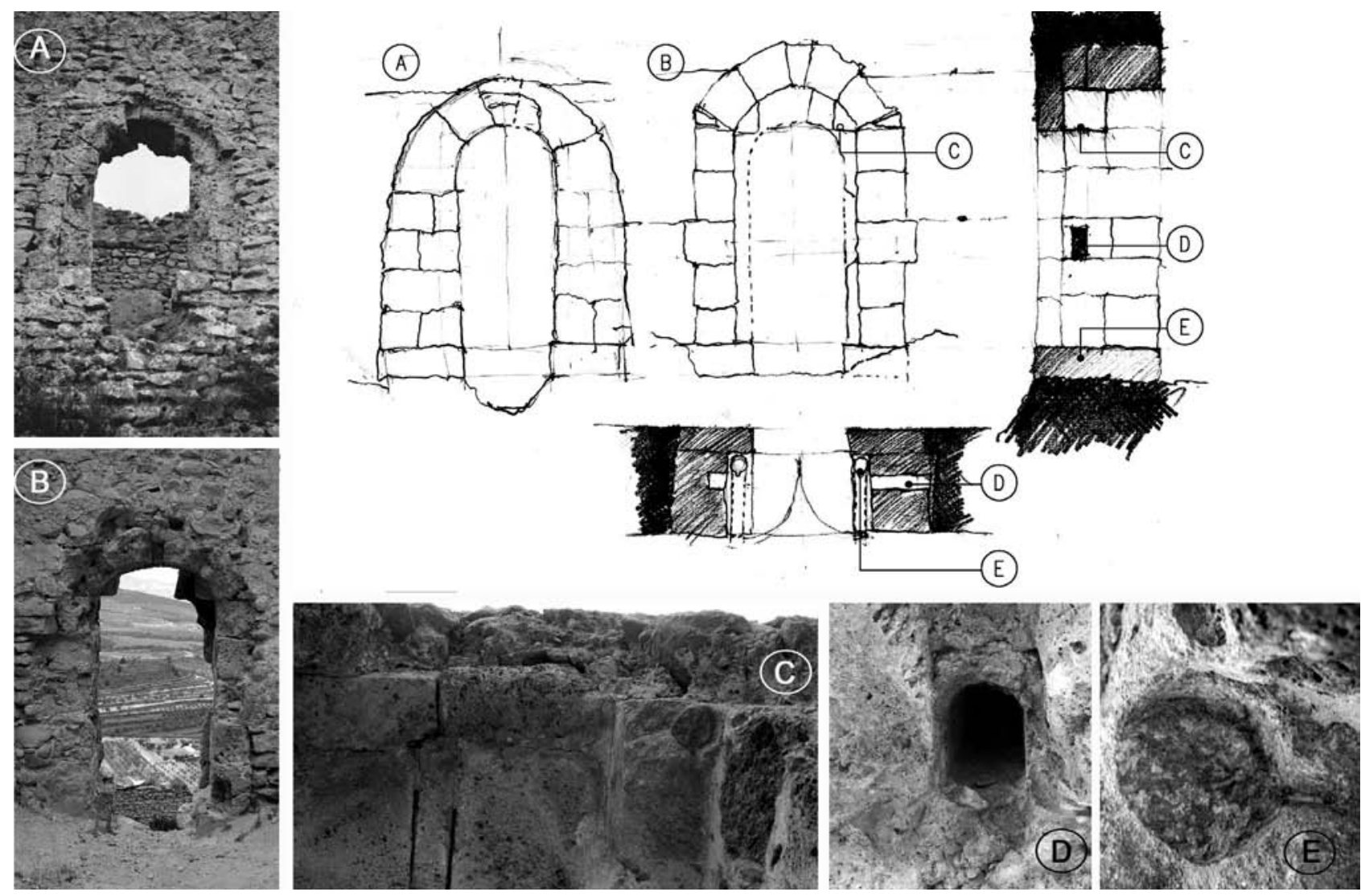

Figura 11: Arco de acceso a la torre. En el croquis y en las fotografías, indicadas con letras: A: Alzado exterior; B: Alzado interior; C: Quicialera ubicada en la parte superior; D: Cerradero en la jamba para colocar la tranca; E: Quicialera ubicada en el umbral.

Como nos explican A. Azkarate e I. García (2004, 26) la guerra medieval fue sobre todo una cuestión de altura: la capacidad defensiva de torres y castillos no dependía tanto del grosor de los muros, (las técnicas de artillería y zapa no estaban tan desarrolladas ni poseían la capacidad destructiva que tendría más tarde la pólvora), como de la relativa inaccesibilidad que se lograba al alcanzar puntos más elevados, reduciendo las posibilidades de alcance de los enemigos y sus proyectiles y aumentando de manera exponencial el radio de efectividad de las ballestas y dardos propios. Para ello era fundamental mantener al adversario a distancia mediante estructuras (los cadalsos y matacanes) que cubrían la zona más vulnerable, los pies de la torre que, por su cercanía, quedaban fuera del radio de tiro de las saeteras. Comunes en las torres de la huerta valenciana debido a su ubicación en terrenos llanos, la existencia de estos recursos defensivos no puede verificarse en Benifallim, pues no contamos con gran parte del alzado, pero es probablemente que su particular emplazamiento le permitiera prescindir de ellos al crear un perímetro de protección que aleja al atacante de la base de la torre y lo coloca en el ángulo de tiro de las saeteras.

El vano principal de acceso a la torre, ubicado en su cara noroeste, merece un estudio particular por ser el único elemento del conjunto que está resuelto con técnica de sillería, que exige mayor cuidado y especialización en la ejecución. Ubicado a unos $3 \mathrm{~m}$ sobre el nivel de apoyo del basamento y realizado en travertino, una piedra blanda apta para la labra pero poco resistente a los agentes atmosféricos, presenta un alto nivel de deterioro.

El arco es rebajado y doble, empotrado durante la construcción de la fábrica de tapial. El exterior mide $1,15 \mathrm{~m}$ de ancho por $1,70 \mathrm{~m}$ de altura de paso y está construido con sillares de $0,20 \times 0,30 \times 0,50 \mathrm{~m}$; el interior es más alto (2,05 $\mathrm{m}$ de altura de paso) y lo componen bloques un poco más grandes, $(0,30 \times 0,40 \mathrm{x}$ $0,60 \mathrm{~m}$ ), contando con piezas especiales y salientes a la altura del dintel donde aún pueden distinguirse los puntos de giro de los cojinetes de la puerta. En estas hendiduras circulares encastrarían los gorrones o pivotes y, por número y disposición, nos indicarían la existencia de una abertura de dos hojas, cuyos bordes estarían protegidos por la luz de paso menor del arco exterior y su apertura restringida durante los ataques por una tranca o viga de madera, que se colocaría de jamba a jamba a la altura del tercer sillar, contando desde el umbral, en dos cerraderos ${ }^{18}$ rectangulares de 0,15 x $0,15 \mathrm{~m}$, y de 0,25 y $1,46 \mathrm{~m}$ de profundidad respectivamente (Fig. 11).

18. Cerradero: Agujero que se suele hacer en algunos marcos para que penetre el pestillo. 

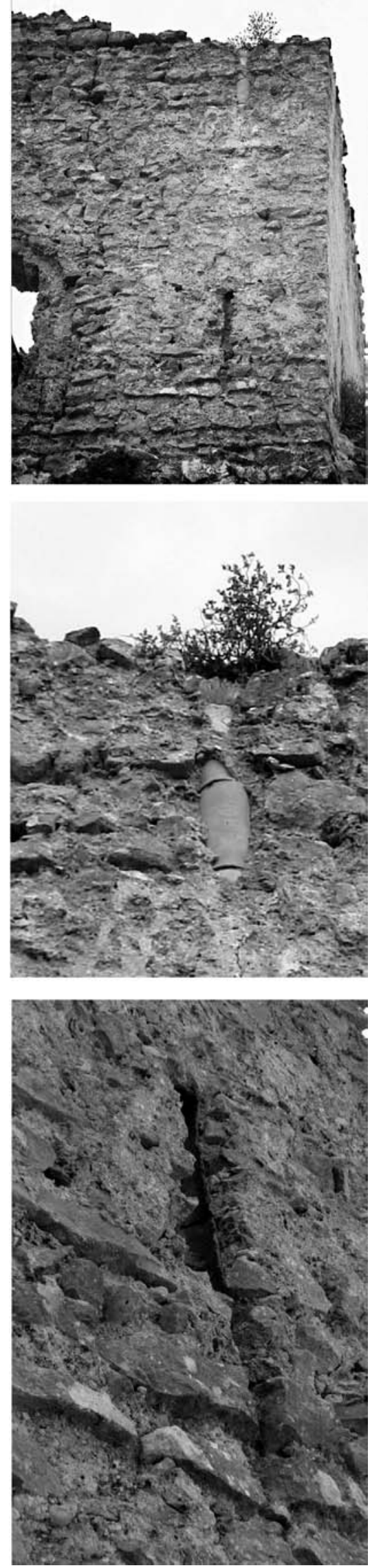

Figura 12: Desagüe embutido en el muro noroeste de la torre. Foto superior: sector de la fachada noroeste donde se distingue el desagüe, en el centro y abajo: imágenes de detalle.
Debido al expolio sistemático de sillares para su reutilización, al nivel de deterioro de los pocos ejemplos conservados y a las modificaciones, restauraciones y restituciones sufridas a lo largo del tiempo, el muestreo de elementos de este tipo en otras fortificaciones dentro de la comarca no es muy amplio. A la hora de intentar encontrar paralelos en otros ejemplos locales, sólo hemos podido observar que la resolución del despiece de la sillería podía tener similitudes con la adoptada en el arco de acceso del castillo de Barxell ${ }^{19}$, aunque las diferencias cromáticas existentes, muy difíciles de evaluar debido al elevado desgaste de las piezas, parecerían indicar el uso de otro tipo de material. Si nos remitimos a modelos extra-comarcales sin abandonar la región valenciana, existen numerosos ejemplos de torres similares en la huerta de Valencia donde detectamos una regularidad en la resolución de los vanos de acceso, que presentan, casi en su totalidad, formas rectangulares y cuadrangulares, utilizando dinteles de madera o de piedra y resolviendo las jambas y umbrales con elementos monolíticos también de piedra (Rodríguez Navarro, 2008, 254).

La ausencia de señales de la existencia de estructuras fijas para salvar la diferencia de altura existente entre recinto y acceso, indican el uso de escaleras de mano recuperables que, en momentos de peligro, se desmontaban y guardaban en el interior de la torre.

Todos estos recursos, destinados a impedir el acceso y el ataque, eran ineficaces si no se contaba con medios para resistir, durante períodos más o menos prolongados, los asedios. Era fundamental que la fortificación dispusiese de espacios que se pudieran destinar al almacenaje no sólo de pertrechos armamentísticos sino también de alimentos, que podrían acopiarse en los niveles superiores del edificio o incluso en el mismo recinto, y sobre todo de agua. Y al respecto, llama poderosamente la atención la aparente ausencia de dispositivos destinados al almacenamiento de agua (aljibes o cisternas), aunque la presencia de un desagüe o atanor de cerámica aún visible en la fachada principal sugiere su posible existencia (Fig. 12), en una posición que por el momento no hemos podido determinar y que podría estar oculta por el potente nivel de sedimentos proveniente del derrumbe de muros y bóveda, que cubre el interior de la torre y que en la zona noroeste llega a alcanzar casi 1,30 m de altura, o enterrada en algún sector del patio.

El recinto es un espacio de unos $280 \mathrm{~m}^{2}$, resultado de explanar parte del terreno anexo a la peña, limitado por una muralla en tres de sus lados y, en la cara restante, por el cordón rocoso complementado con un cuarto muro, del que se aprecian restos sobre la peña a unos $6 \mathrm{~m}$ al noroeste de la torre (Fig. 13). Hay una importante variación de nivel entre el patio y las parcelas

19. Castillo ubicado en el término municipal de Alcoy, a unos $6 \mathrm{~km}$ de la capital del municipio en dirección de Banyeres, cuyo origen ha sido datado en el siglo XIII. 


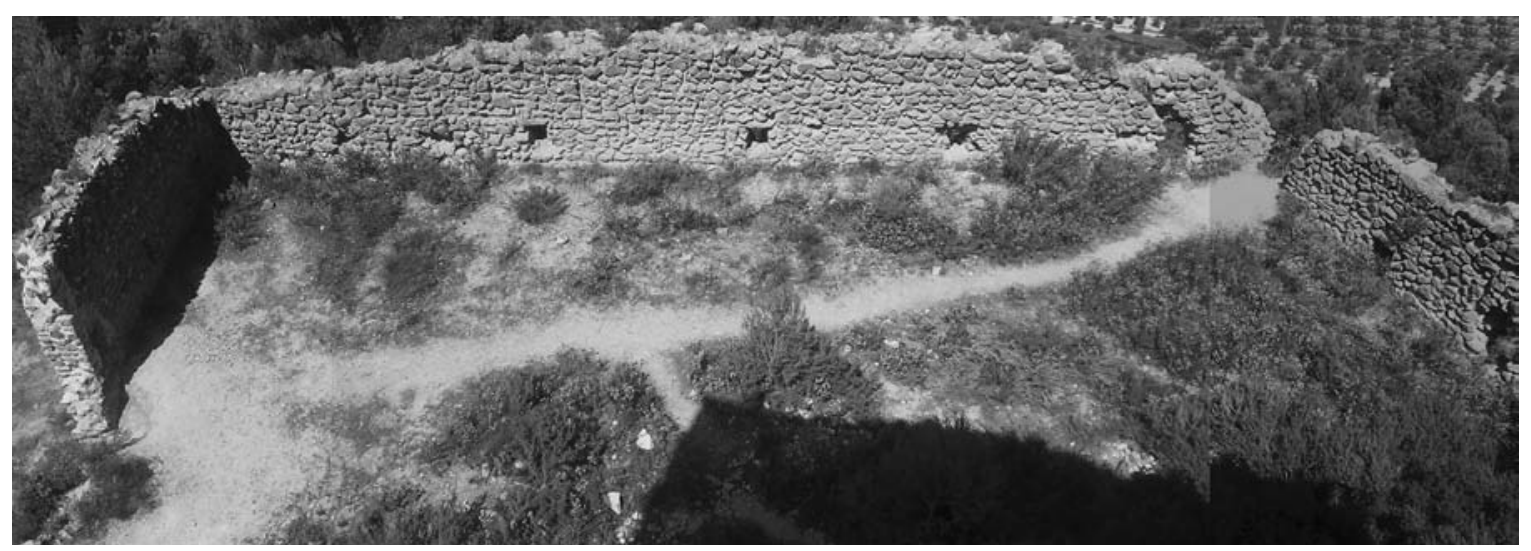

Figura 13: Vista del recinto desde la torre.

exteriores y adyacentes a los muros de cierre, que alcanza alturas cercanas a los 3,60 m. Sin embargo, dicha diferencia podría reducirse si tenemos en cuenta que la acumulación de sedimentos tiene, tomando como referencia la altura del antepecho de las aspilleras, en las que el tirador probablemente estaría de pie, una altura mínima de 1,25 m, o niveles mayores en el caso de que existiese un paso de ronda.

El ancho promedio de los muros es de $0,80 \mathrm{~m}$, medida que resulta estrecha en comparación a los de la torre, pero que es proporcionalmente correcta a su altura probable, que sería de unos $7 \mathrm{~m}^{20}$. El muro sureste, tiene una longitud de unos $16 \mathrm{~m}$, aunque sólo la mitad sobrepasa en altura el nivel del interior del patio, siendo el resto sólo visible por tramos desde la parte exterior o siguiendo su traza en el suelo, y presenta tres saeteras de medidas iguales a las de la torre $(0,50 \mathrm{~m} \mathrm{x}$ $0,50 \mathrm{~m}$ en la cara interior del muro y de $0,20 \mathrm{~m} \times 0,50$ $\mathrm{m}$ en la exterior $)^{21}$, existiendo una diferencia de nivel entre interior y exterior del muro de unos 2,50 m. El muro noroeste, tiene unos 21,60 m de longitud, conserva tres saeteras e indicios de una cuarta, con medidas similares a las del muro anterior y una diferencia de nivel entre el suelo en la cara exterior e interior de unos 3,60 m. El último de los muros, el noroeste, de una longitud de unos $19 \mathrm{~m}$ y tres saeteras, adapta su trazado a los desniveles del terreno, pues uno de sus extremos asienta sobre el cordón montañoso donde se erige la torre.

La técnica de construcción de toda la muralla es también un tapial de tipo mixto, pero de diferente factura que el de la torre. Las piedras colocadas dentro del encofrado son mucho más grandes, el contenido

20. Para el cálculo de la altura aproximada, consideramos completa la tapia más alta dentro de la altura promedio. Si en cambio tomáramos como punto de referencia el tramo de muro que trepa a la peña, e igualáramos alturas, tendríamos como resultado más de $10 \mathrm{~m}$ de altura, por lo que el muro sería esbelto en proporción a su espesor.

21. Una de las saeteras ha sido recientemente restaurada y se le ha dado a ambas caras la medida correspondiente a la cara interior, perdiendo su abocinamiento característico. en cal de la mezcla parece ser menor y las marcas dejadas por los travesaños son diferentes en forma y modulación, tienen sección redonda y la distancia entre hiladas es de $0,90 \mathrm{~m}$. No conserva prácticamente revocos, salvo en la parte inferior de la cara exterior de los muros noroeste y noreste, presentando un desgaste del material de relleno y el calicastrado muy elevado, provocado por las características de su emplazamiento a media pendiente, en contacto con el terreno y con una gran diferencia entre el nivel del suelo de la cara interior y la exterior, que lo convierte en barrera de las escorrentías del agua de lluvia provenientes de las zonas más altas. A ello se suma la presencia de árboles y arbustos de gran porte que favorecen el mantenimiento de un constante nivel de humedad y el consiguiente ataque de la vegetación invasiva. Sin embargo, es probable que el desgaste se haya acentuado por la merma en la calidad del muro debido quizás a cierta premura en su construcción, ya que aparentemente hay menor contenido de cal en la mezcla, lo que produce un fraguado más rápido y por consiguiente la aceleración del proceso, redundando en un ahorro de plazos de ejecución y mano de obra, que con el tiempo se refleja en la menor durabilidad de la estructura (Fig. 14).

En la interpretación estratigráfica hemos detectado que los muros sudeste y noreste se adosan al muro noreste, no existiendo entre ellos traba alguna, lo que indicaría, siguiendo la lógica de la construcción con cajones de tapial, que este último es el que primero se ejecutó. La causa de la adopción de esa inadecuada resolución de los encuentros entre tramos puede deberse a distintos motivos; en el caso del ángulo este, podría atribuirse a dificultades para el armado del encofrado de esquina debido a la necesidad simultánea de solidarizar al muro noreste con la peña para crear una continuidad; en el ángulo norte, nos inclinamos más por una reconstrucción debido al desplome del muro noroeste o a una redefinición del trazado del mismo luego de la construcción del primer muro.

El análisis estratigráfico de las estructuras murarias de todo el conjunto evidencia que recinto y torre no fueron realizados en una misma fase. La manera 

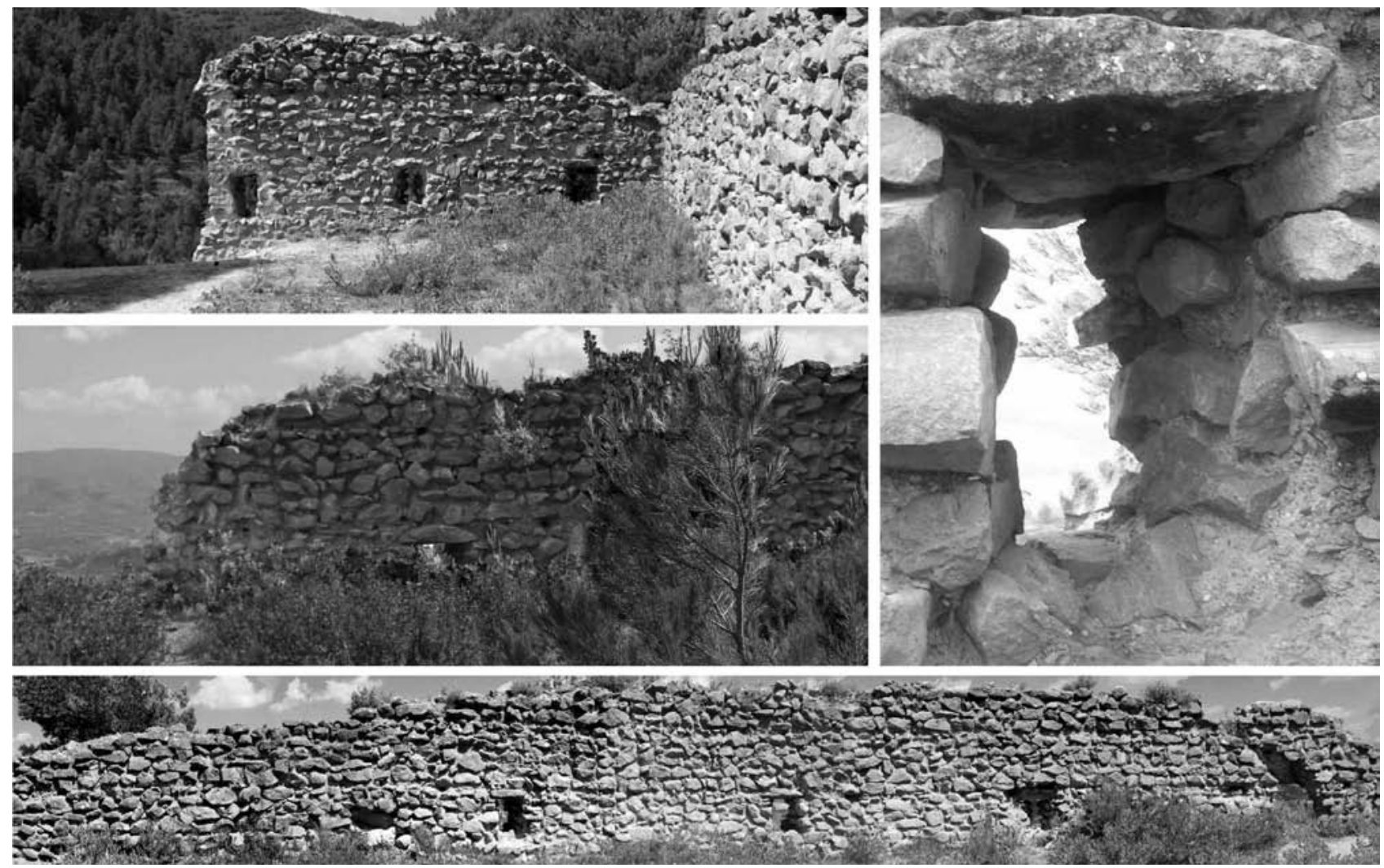

Figura 14: Muros del recinto. Imágenes de la cara interior muros aún existentes: arriba, muro suroeste; en el centro, muro noreste y en la parte inferior, muro noroeste. A la derecha, detalle de saetera.

de emplear la técnica constructiva, y la calidad de la ejecución, denotan la intervención de mano de obra de diferente preparación o inmersa en circunstancias distintas. La necesidad de reducir tiempos y/o costes en la construcción del recinto, en detrimento de la calidad, muestra claramente la existencia de al menos dos etapas principales más una serie de intervenciones menores, destinadas a reconstrucciones parciales y consolidaciones, cuya cronología, a excepción de las acciones contemporáneas, no podemos definir con precisión.

Los acontecimientos que rodearon la conquista cristiana en la fase repobladora determinaron la permanencia de la población indígena como fuerza de trabajo ante la falta de colonos y, a partir de su empleo como mano de obra, una continuidad en la utilización de determinadas técnicas constructivas, lo que dificulta distinguir las construcciones realizadas en esta época de las que pertenecen a período andalusí. Sin embargo, determinadas particularidades de los muros del recinto como su espesor, altura y la presencia de saeteras no guardan similitud con los cercados carentes de recursos defensivos adicionales, y muchas veces de pequeño espesor, que caracterizaban a estos espacios anexos a las torres de alquería (Bazzana, Guichard y Cressier, 1988, 122), característica que unidas al hallazgo del fragmento cerámico inserto en la masa del paramento noreste, evidencia su ejecución en época post-andalusí.

\section{EL CASTILLO COMO PARTE DEL SISTEMA DE ESTRUCTURACIÓN DEL PAISAJE}

“...el paisaje, como todo producto humano, es la objetivación de una intención, sentido y racionalidad previa que se actualizan en elementos formales concretos y que, como tal, esos elementos deben representar de algún modo (siquiera sea distante) los contornos de aquella racionalidad, podemos intentar desarrollar una descripción del paisaje que deconstruya éste y permita aislar los elementos y relaciones formales que lo constituyen..."(Criado, 1999, 9).

La arquitectura es el reflejo de la manera en que una sociedad percibe su entorno físico y, en consecuencia, responde con una forma determinada a códigos de uso, esquemas mentales y a una particular concepción del espacio (Mañana et alii, 2002, 14-15). Es por ello que los objetos arquitectónicos no pueden estudiarse como entes descontextualizados, pues forman parte de complejos sistemas de estructuración del paisaje que reflejan la manera de organizar el mundo de los grupos humanos que los habitan (Criado, 1999)

En el epígrafe anterior hemos analizado al castillo de Benifallim en cuanto a sus características como objeto arquitectónico, partiendo de datos por nosotros recabados mediante la aplicación de metodología arqueológica, trabajo de registro que conformaba, como ya puntualizamos, el objetivo primordial de éste trabajo. Sin embargo, creemos que este primer acercamiento 
al conocimiento de la fortificación quedaría incompleto sin un cambio de nivel de aproximación, un necesario distanciamiento del objeto que nos permita observar que tipo de relación establece con su entorno para intentar analizar, a partir de ello, qué papel jugaría dentro del esquema general de funcionamiento de las sociedades que habitaron la comarca y sus patrones de asentamiento. De esta forma intentaremos explicar el porqué de su construcción y de su particular emplazamiento, pues, como puntualiza P. Cressier (1991, 405) “...la función de una fortaleza se deduce a menudo mucho más del conjunto de la red fortificada regional y de las relaciones espaciales con otros tipos de asentamiento, que de la sola estructura arquitectónica...”.

Para poder trazar los diferentes mapas de ocupación era imprescindible poder ubicar los yacimientos detectados en la comarca en su correspondiente marco espacio-temporal, lo que implicaba encarar un análisis pormenorizado de los mismos, (estudio y datación de los vestigios hallados, consulta de las escasas memorias de excavación y prospección en algunos casos muy antiguas o inexistentes, pues los materiales provienen de donaciones y hallazgos casuales, análisis de la documentación histórica y ejecución de nuevas tareas de exploración y registro para actualizar o completar la información existente), trabajo que excedía los alcances de esta etapa de nuestra investigación, que intentaba ser una primera aproximación al tema. Es por ello que hemos decidido elaborar este apartado a partir de una síntesis de la bibliografía existente, basándonos principalmente en los trabajos de J. Torró (1990,1992, $1996,1998,2006)$, que ha centrado gran parte de su tarea investigadora en nuestra zona de estudio, (con la colaboración, en algunos artículos, de P. Ferrer (1996a; 1996b), J. Ivars (1989) y J. Segura y Marti (1990;1991) y de P. Guichard (1976; 1982; 1987a; 1987b; 1987c; 2001a; 2001b; 2001c) en particular las publicaciones dedicadas a la región valenciana. También hemos consultado la obra de R. Azuar Ruiz (1989), en particular su tesis doctoral publicada bajo el nombre de "Denia islámica", de P. Cressier (1991; 2004), de A. Bazzana (1988) y de M. Acien (1995) sobre castillos rurales y fortificaciones islámicas, de C. Ferragud Domingo (2003) sobre la evolución de Cocentaina, de Ferrando i Frances (1986) sobre el "Llibre del Repartiment" y de C. Barceló Torres (1983) sobre toponimia arábiga del País Valenciano, (que nos han permitido rastrear la posición aproximada de las alquerías) y finalmente, el de I. Donoso Jiménez (2006), que nos aportó información sobre los poblados moriscos. Creemos importante nombrar también a aquellos autores cuyo aporte nos permitió entender la evolución de la región a partir de los primeros vestigios de ocupación humana hallados en el castillo de Benifallim, pertenecientes a la Edad del Bronce hasta la ocupación islámica: F. Molina Hernández (2004) (Prehistoria desde paleolítico medio a Edad del Bronce), I. Grau (2000; 2002) (época ibérica y romana, esta última con el aporte de I. Garrigós (2007)) y S. Gutiérrez Lloret (1982) (época alto-medieval).

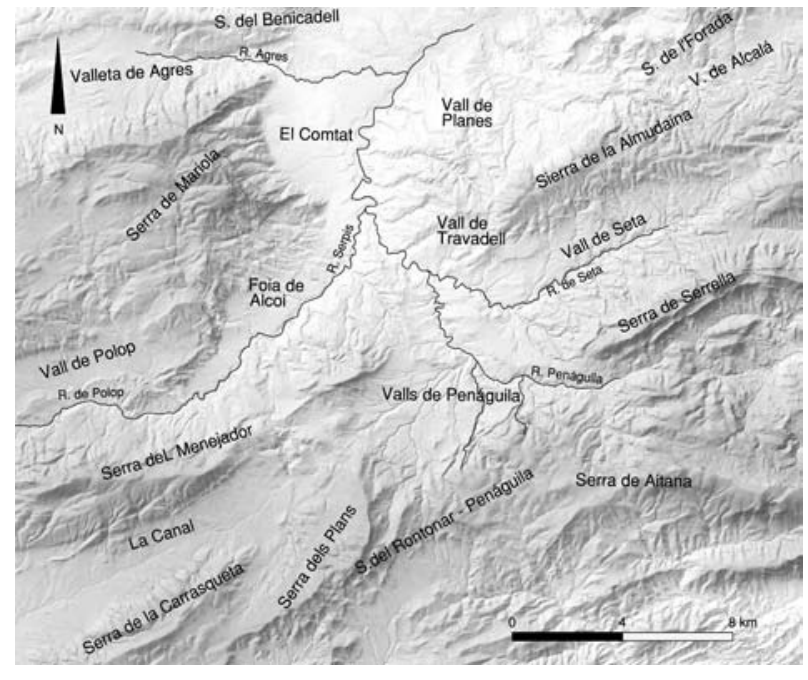

Figura 15: Rasgos geomorfológicos de la zona estudiada. M.D.T. Ortofoto obtenido del Visor Web de la Conselleria de Medi Ambient, Aigua, Urbanisme i Habitatge.

El área que analizaremos corresponde al conjunto comarcal denominado como "Valles del Alcoi"o "L'Alcoià-El Comtat", que se inscribe en pleno conjunto montañoso del prebético valenciano, y está formada por un conjunto de cadenas de sierras que delimitan una serie de valles fluviales secundarios cuyos ríos desagüan al Serpis o rio d'Alcoi, que recorre el valle principal, quedando sus límites conformados al norte por la Sierra de Benicadell, al oeste por la Sierra de Mariola, que limita dos corredores naturales: la Vall d'Agres y la Vall de Polop, al sur y sureste por el macizo de Aitana, formado por las Sierras de Rontonar, Penàguila y Aitana que delimitan la Vall del Frainós o de Penàguila, al este por la sierra de Serrella y de Almudaina, que enmarcan la Vall de Seta a la que sigue la Vall de Planes, bordeada por la Sierra de la Foradà y al noreste la Vall de Pertpuxent (Fig. 15).

En este escenario natural de relieve quebrado y fronteras muy marcadas, la comunicación con las comarcas vecinas se encuentra restringida a un número reducido de puntos de acceso; la accidentada orografía también ha condicionado el trazado de los caminos y limitado el tipo de tránsito a la utilización casi exclusiva de la caballería hasta época moderna, lo que lógicamente ha determinado una continuidad en los recorridos. Basándonos en las vías de comunicación utilizadas durante el período de los reinos taifas planteadas por R. Azuar Ruiz (1989, 353-357)22, hemos

22. R. Azuar propone dos puntos importantes de confluencia de caminos dentro de la región, Cocentaina y Penàguila. En Cocentaina coiciden la ruta que viene de Denia, en dirección este-oeste y la de Xàtiva (norte-sur), uniéndose a partir de esta localidad en una sola que llegaría a Villena después de cruzar el Castellar de Alcoi, Ibi, Castalla y Biar. De la misma ruta de Denia, se desvía un camino en Planes que uniendo Almudaina y Millena llega a Penàguila donde después de cruzar el Port de Tudons, se divide en 4 vías, 


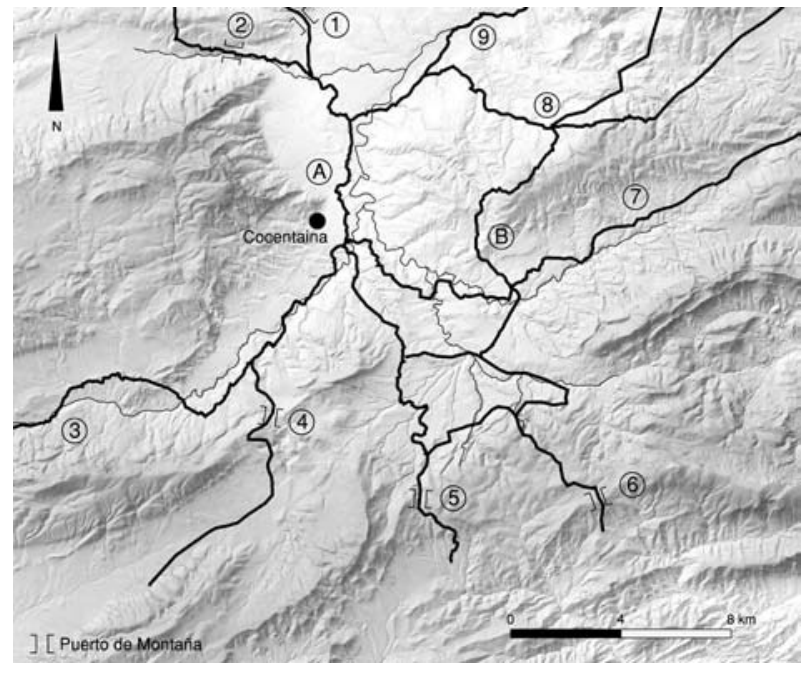

Figura 16: Red viaria. A: Eje norte-sur por la Foia de Alcoi, B: Eje norte-sur por los valles de Penàguila. Caminos provenientes de las comarcas vecinas. 1: de la Vall de Albaida a través del puerto del mismo nombre. 2: de la Valleta de Agres desde el Alto Vinalopó a través de l'Estret d'Agres. 3: de la Foia de Castalla a través del Cami Vell de Ibi. 4: de la Foia de Castalla a través de La Canal. 5: de la Vall de la Torre a través del Port del Rontonar. 6: de la Vall de la Torre a través del Port de Tudons. 7: de la Vall de Seta. 8: de Dénia a través de los valles de la Marina. 9: de la Vall de Perputxent.

intentado reconstruir la trama de las rutas principales que cruzarían el territorio, precisando los trazados y confirmando la presencia de vías menores a partir de las propuestas desarrolladas para época ibera por I. Grau Mira $(2000,150-167)^{23}$. La red viaria quedaría entonces conformada por dos ejes de comunicación importantes dirección norte-sur (en el sentido del valle principal), destacando el que acompaña el curso del Serpis, pues en el confluyen, en un área coincidente con los alrededores de Cocentaina, los principales caminos que trascienden la comarca y la comunican con las regiones adyacentes ${ }^{24}$, dato que nos revela la

una que llega a Altea, pasando por Guadalest y Callosa, la segunda que llega a la Vila Joyosa, cruzando Sella y Orxeta, la tercera que llega a Relleu donde se bifurca para unirse en Orxeta con la anterior u optar por seguir hasta Aigües de Busot y de allí a Alicante y la cuarta que, por Torre de les Maçanes cruzando Xixona, llega también a Alicante.

23. El análisis realizado por I. Grau en su tesis doctoral propone, a partir del estudio de las características del paisaje (puertos de montaña, desniveles, etc), posibilidades de caminos adaptados a la morfología del área obtenidos mediante la generación de modelos digitales que consideran, tomando los puntos de partida y destino y los valores de pendiente, las rutas óptimas y de menor esfuerzo. Este trabajo, realizado con el fin de trazar una hipótesis de la caminería en la época ibera, tiene el mérito de comparar los datos obtenidos con los estudios y crónicas sobre vias de comunicación en las distintas épocas, lo que lo hace válido para nuestro trabajo, ya que incorpora los datos aportados por R. Azuar y los complementa.

24. Los ramales que llegan desde las comarcas vecinas son: el proveniente de la Vall de Albaida, que cruza a través del importancia de este asentamiento a nivel comarcal. Paralelo a este eje principal, se desprende un eje secundario que, proveniente de la ruta de los Valles de la Marina y pasando por Penàguila, se bifurca en dos ramales que cruzan a la Vall de la Torre en dirección a Alicante, uno por el Port de Tudons, pasando por la Vila Joyosa y otro por el paso del Rontonar vía Torre de les Maçanes y Xixona. A este sistema se incorporarán finalmente los caminos provenientes de la Vall de Pertpuxent, de la Vall de Seta y el desvío a Ibi a través de La Canal (Fig. 16).

Los indicios más antiguos, aportados por el registro arqueológico en el emplazamiento donde se ubica el castillo, pertenecen a la edad del Bronce. Son restos muy afectados debido a las ocupaciones posteriores, probablemente de un poblado de pequeñas dimensiones y clara vocación agrícola, a juzgar por los hallazgos realizados (dientes de hoces, cerámica de almacenaje y molino) que, a semejanza de otros asentamientos similares (el Alt del Regadiu, el Calvari de Penàguila y el Cami de la Condomina), se ubica en ceros ligeramente destacados de su entorno, próximos a corredores naturales y zonas fértiles $y$, asociados a otro tipo de establecimientos (els Tossals d'Aitana o Barranc del Frainós, El Pitxòcol, La Serreta y El Castell de Penàguila) que, situados en sitios enriscados, de difícil acceso y gran visibilidad, ejercen la función de control del territorio (Molina Hernández, 2004, 115).

Si bien las evidencias arqueológicas de ocupación del sitio en época ibera y romana se reducen a escasos fragmentos cerámicos, probablemente parte de rellenos y movimientos de tierra producto de tareas de laboreo agrícola, un análisis a nivel comarcal de patrones de asentamiento evidencia una continuidad en la ocupación de sitios que, por su posición de dominio sobre porciones de territorio, configuran puntos estratégicos, y que va acompañada de fenómenos de movimiento de ascenso y descenso de la población desde estas posiciones a los valles, que se darán con cierta continuidad hasta la implantación del sistema feudal.

Es así como la compleja organización sociopolítica ibera se traducirá en una ocupación del territorio articulada, en este caso, en torno a una ciudad dominante, La Serreta, y a una serie de oppida, poblados fortificados y estables a lo largo del tiempo, (el Castell de Penàguila, el Castellar d'Alcoi, el Pic Negre, el Castell de Cocentaina) (Grau, 2000, 143-206) será reemplazada por un esquema absolutamente diferente en época romana, con el abandono gradual de los establecimientos en altura en favor de una articulación territorial basada en núcleos de segundo orden, las villas, que configuran un sistema alrededor del cual se asentarán los núcleos menores ante la ausencia dentro de la comarca de una

puerto del mismo nombre, el de Dénia que atraviesa los Valles de la Marina, la Valleta de Agres, que comunica con el Alto Vinalopó, el de la Foia d'Alcoi, que sigue el curso de los ríos Serpis y Polop. 
ciudad que cumpliera con dicha función de manera activa $^{25}$ (Grau y Garrigós, 2007, 145-147).

Sin embargo, en un momento que podría situarse entre los siglos VI-VII, vuelve a constatarse una disminución de los asentamientos en el llano, una fuerte regresión de los establecimientos productivos y una formación y/o reocupación de asentamientos de altura, algunos de ellos poblados ibéricos abandonados en la época del Imperio (Torró, 1990, 44), situados en áreas marginales, periféricas y estratégicas, fácilmente defendibles y con acceso a zonas cultivables, lo que les otorgaba una relativa autosuficiencia. Producto de la crisis agraria y económica del sistema productivo romano, agravada por plagas y epidemias, esta dispersión de parte de la población (Gutiérrez Lloret, 1992, 677-685) constituye un fenómeno territorial durante el momento de la conquista islámica que será reaprovechado durante los dos siglos siguientes como soporte para el emplazamiento de los husṣūn (castillos) andalusíes (Torró, 1990, 46).

Los primeros asentamientos islámicos en la región, datados en los siglos VIII y IX, son habitados por tribus disidentes, probablemente en su mayoría bereberes ${ }^{26}$, que ocupan las alturas durante épocas de rebelión al poder omeya. El Pic Negre, único yacimiento de la comarca que ha podido ser identificado hasta el momento como perteneciente a ese periodo, estaba ubicado en una posición de altura, caracterizada por el amplio dominio visual tanto del valle principal como del espacio circundante, controlando todo el sector central de la cuenca del Serpis y los accesos a la misma desde los valles tributarios. Las tierras cultivables se ubicaban en un radio relativamente cercano aunque no inmediato pues las necesidades primordiales de protección hacían viable la incomodidad de los desplazamientos. Esta estrategia de ocupación es la óptima de acuerdo al carácter del asentamiento, posiblemente un refugio

25. I. Grau e I. Garrigós (2007) sugieren que la ausencia de un núcleo urbano de importancia dentro de los Valles de Alcoy da a las villas el papel de articuladores del territorio, hecho que no descarta su dependencia administrativa de alguna de las ciudades importantes de la region Danium, Saetabis, Allone o Lucentum. Los autores proponen a la primera como la más probable por estar ubicada en una situación más favorecedora en cuanto a las comunicaciones que con ella pueden establecerse.

26. J. Torró y P. Ferrer $(1996 b, 170)$ formulan esta hipótesis de la predominancia del elemento beréber en el poblamiento inicial de la región a partir de los hallazgos detectados. La presencia de elementos decorativos de procedencia magrebí en la decoración de las piezas cerámicas encontradas en el Tossal del Barxell, Tossal del Moro, Port de Gorga, Castell de Penàguila, el Pic Negre y el Castellar de Alcoi, todos yacimientos de ocupación antigua, remarcaría el probable carácter beréber de esos asentamientos, siempre haciendo la salvedad de la dificultad de la datación precisa de dichos restos debido a la insuficiencia de trabajos arqueológicos (la mayoría de las piezas provienen de antiguas excavaciones, recogidas superficiales y hallazgos fortuitos).

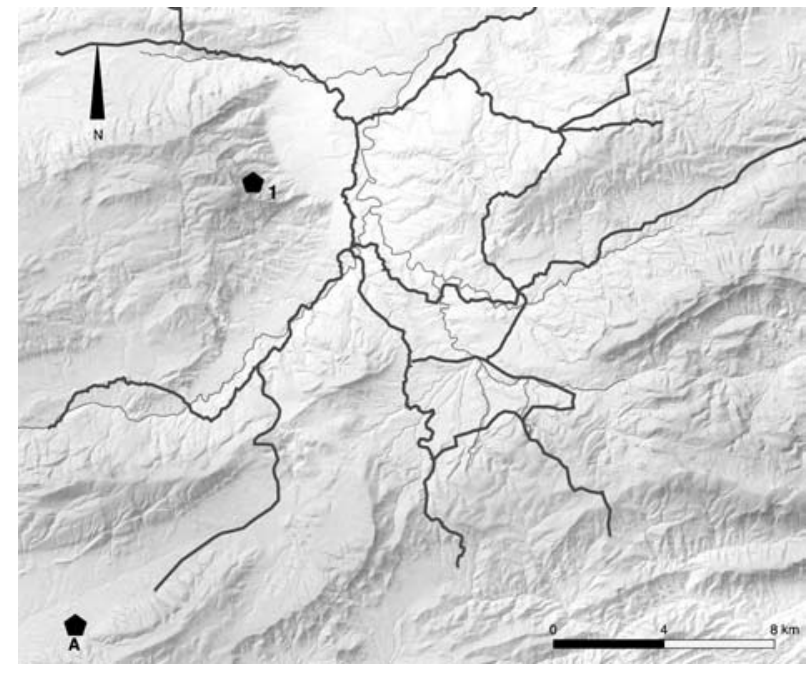

Figura 17: Asentamientos siglos VIII-IX. A: Poblado. 1: Pic Negre.

de bereberes en oposición al poder central (Torró y Ferrer, 1996a, 170) (Fig. 17).

A partir del siglo X, la estabilidad política derivada del califato y la necesidad de establecer mecanismos de control estatal, cambia el perfil de los asentamientos y los engloba dentro de su sistema administrativo. Se fuerza el abandono de las fortificaciones ubicadas sobre sitios apartados e inaccesibles y se obliga a la población a descender al llano (Acién, 1995,18-19; Torró, 1998, 398-400). Construido ex-novo o sobre sitios enriscados existentes fácilmente defendibles y estrechamente vinculados a los centros productores ubicados en los fondos de valle, el nuevo sistema defensivo estará constituido por verdaderos poblados amurallados, que aprovechan las superficies amesetadas de los cerros para edificar las áreas domésticas (Gutiérrez Lloret, 1992, 696). En nuestra zona de estudio y coincidiendo con el abandono del Pic Negre se produce la ocupación del Castillo de Cocentaina, en el mismo cerro pero a menor altura, vigilando la cuenca de Serpis al que se suman, en un segundo plano de importancia, el Castellar de Alcoi, dominando la Vall de Polop y el Tossal del Moro, controlando la Vall de Penàguila. Los tres sitios determinan un área de influencia estratégica que, abarcando el corazón del sistema de valles y nudo de las vías de comunicación, coloca bajo su vigilancia y protección a los enclaves menores dedicados a la producción (Fig. 18).

Esta combinación de un núcleo en altura del que dependen núcleos de llano es el germen de la red de asentamientos que configurarán el espacio agrario andalusí y cuya unidad, la qarya, se origina según P. Guichard (1976), a partir de modelos tribales de agrupación social de orientales y magrebíes asentados a partir del s. VIII, unidades étnicas cerradas cuya base de cohesión era el parentesco patrilineal y donde todos los miembros creían descender de un antepasado común. Por esta razón, la frecuente identificación mediante topónimos no distinguía al sitio sino que evocaba la 


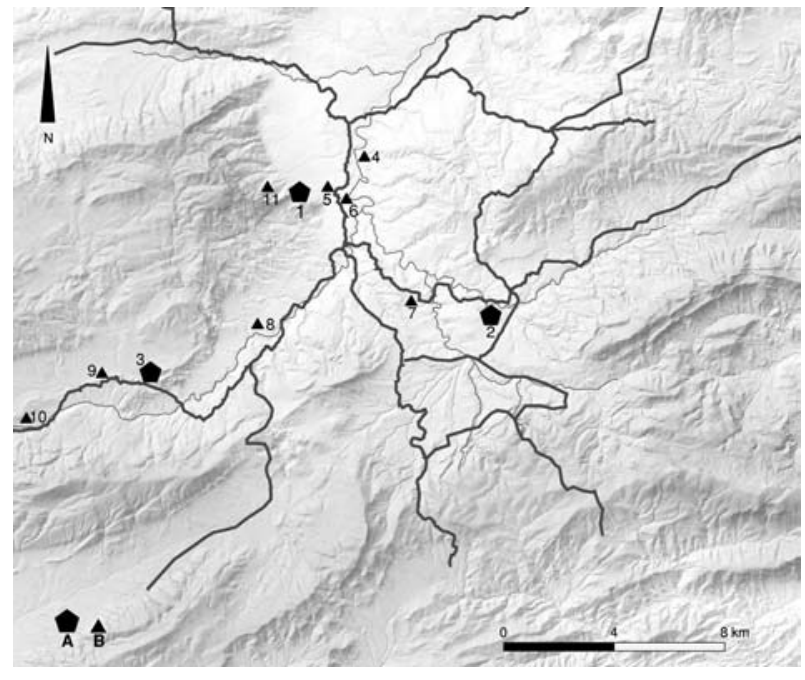

Figura 18: Asentamientos siglo X - XI. A: Poblado fortificado. B: Núcleo de llanura. A: 1: Castillo de Cocentaina. 2: Tossal del Moro. 3: Castellar de Alcoi. B: 4: El Sompo. 5: Calle Gadea Pons. 6: Camí del Puntarro. 7: Tossalet. 8: Benisaidó. 9: Barxell. 10: Polop.

apropiación colectiva de la tierra por el grupo humano allí establecido (Guichard, 1987, 180), que se distribuía en un conjunto de hogares o caseríos geográficamente aislados cuyo tamaño fluctuaba entre unas diez a cincuenta familias, donde los procesos productivos se ejercían de manera colectiva y el patrimonio del clan no era fragmentable por división o herencia. Las qarya-s, según J. Torró (1990, 48-49), constituían una forma de segmentación del espacio rural no siempre bien delimitada, pues “...no existía una noción muy clara de lo que se puede entender como propiedad de la tierra..." organizándose territorialmente en redes, diseminadas irregularmente pero siempre en equilibrio con el tamaño de las comunidades asentadas y la extensión y calidad de las tierras de cultivo. P. Cressier $(1991,1999)$ propone la existencia de un estrecho vínculo entre las tres realidades: fortificación, sistema de irrigación y qarya como base de la estructuración de los espacios agrarios andalusíes ${ }^{27}$. Las qarya-s se agrupaban, a su vez, en comunidades rurales o aljamas $^{28}$,

27. Las qariya-s suelen agruparse, según P. Cressier, de manera más o menos sistemática alrededor de la fortaleza de que dependen. En los casos en que las condiciones naturales permiten la agricultura de regadío, el territorio se organiza no sólo en relación al castillo, sino también alrededor de un centro agrícola irrigado donde se distribuyen las qarya-s. Estos tres niveles de relación, castillo y división políticoadministrativa del territorio, territorio y núcleos de regadío, sistemas hidráulicos y sociedad segmentaria andalusí son los que organizarían el espacio agrario, al menos en la zona analizada por P. Cressier que es Andalucía oriental.

28. La aljama estaba virtualmente compuesta por todos los adultos capaces de portar las armas y a menudo estaba dirigido por un grupo de ciudadanos notables (Según Masqueray, 1983, 50,80, citado por A. Bazzana P. Guichard y solidarias y fuertemente organizadas, que ejercían derechos colectivos sobre el territorio que ocupaban y sobre el castillo a cuyo alrededor se concentraban, identificándose ambos (castillo y aljama) con el mismo topónimo (Guichard, 1987, 177).

El siglo XI es testigo del abandono del poblado en altura y de la relocalización de sus habitantes en llanos y laderas, fenómeno que multiplica el número de qarya-s, que se ubican preferentemente a lo largo de los valles fluviales y de las vías de comunicación, en búsqueda de un mejor rendimiento productivo pero aumentando su vulnerabilidad.

La aparición de nuevos castillos, producto de la inestabilidad política que culminará con la ocupación almorávide y del impacto que producen en la zona las primeras incursiones de los cristianos ${ }^{29}$, probablemente esté en relación "...con la afirmación de la autonomía de las aljamas frente al poder evanescente de los soberanos taifales...", (Torró y Ferrer, 1996b, 182) donde el qá'id o alcalde, sería integrante de un clan interlocutor del poder, responsabilizado, llegado el caso, de la recaudación fiscal (Torró, 1998, 405).

Estos castillos refugio se ubicaban en zonas enriscadas de topografía irregular, con fuertes pendientes y bruscos desniveles interiores. Carentes de hábitat permanente y disociados de los sectores habitados, estaban configurados como un gran recinto vacío, sin otra construcción, en la mayoría de los casos, que una o varias cisternas y un cierre amurallado, incompleto y sencillo, sin dispositivos de flanqueo, que se acopla a la topografía complementando las defensas naturales en el refuerzo de los flancos más débiles (Torró, 1998, 401-405).

A este grupo se adscribían en esta comarca las fortalezas de Penàguila, Pla de la Casa, Margarida, Alcalà, Agres, el Castellar y Cocentaina.

El sistema espacial quedaba entonces estructurado por un sistema de fortificaciones, probablemente gestionadas por las mismas comunidades rurales bajo cuya influencia se hallaban las alquerías, situados a lo largo de los valles fluviales y las vías de comunicación. Ubicadas muchas de ellas, en puntos de acceso a la comarca, generaban radios de protección y podían establecer, gracias a su posición en altura, ejes de interconexión visual para una rápida transmisión del

P. Cressier, 1988, 289). Con frecuencia era, en realidad, una especie de Consejo de Asuntos de la comunidad, semejante al encontrado en época contemporánea en regiones del Occidente musulmán, como la Kabilia (Guichard, 1987a, 177).

29. Las incursiones de los cristianos se encuentran verificadas arqueológicamente en el Castellar de Alcoi, donde aparece, a fines del siglo XI, un potente nivel de carbones y cenizas cubiertos por derrumbes junto a enterramientos de individuos con signos de muerte violenta, no constatándose su reocupación hasta fines del s. XII. Coincidente con estos hechos se constata la desaparición del Tossal del Moro, el Tossalet, La Canaleta, el Puntarro y el Sompo, donde se registra una brusca interrupción de la ocupación y el posterior abandono. (Torró y Ferrer, 1996b, 186-188). 
alerta en caso de peligro. Es así como el Castillo de Agres controlaba el acceso desde la Valleta, los castillos de Margarida y de Alcalá se ubicaban reforzando el punto de confluencia de los ingresos desde el Valle de Gallinera y el de Alcalá, El Castellar vigilaba las comunicaciones con el Valle de Polop, el de Pla de la Casa el Valle de Seta, el de Penàguila se situaba en un punto intermedio de las vías de acceso a los Ports de Tudons y del Rentonar y el Castell de Cocentaina protegía el área central de la comarca (Fig. 19).

Las últimas décadas del s. XII son testigos del avance de los cristianos. Tras la caída de varias ciudades importantes, como Tortosa, Teruel, Lleida y Cuenca, la región, entonces densamente poblada, se transforma en zona de frontera dando inicio a un período de construcción y/o reforzamiento de estructuras defensivas ${ }^{30}$.

Tal como explica J. Torró, este proceso de dinámico y exponencial crecimiento de las fortificaciones, sólo explicable ante la necesidad de contar con un sistema de defensa integral ante la inminencia de la agresión, fue posible principalmente gracias a la existencia de “...aljamas muy sólidas y fuertemente articuladas hecho relacionable con la importancia de los asentamientos beréberes en el país..." (Torró, 1998, 410411). Estas entidades fueron las principales responsables de su construcción y sólo puede sugerirse cierta intervención del estado almohade en algunas sofisticaciones técnicas y regularidades arquitectónicas que se observan en los castillos de la época, (aspilleras, antemurales, bastiones de flanqueo, ingresos en recodo, lanceras, etc), que sugieren la posible aportación de técnicos especializados ${ }^{31}$. Llegados a este punto, es importante aclarar que los castillos y torres andalusíes de la región no parecen responder a un único plan estratégico de fortificación de iniciativa estatal. Son el resultado de un proceso de agregación a lo largo del tiempo y si bien existe intervisibilidad entre ellos, no ha sido como resultado de un intento de crear líneas defensivas, sino la consecuencia lógica de la densificación del sistema de fortificación y de su ubicación en puntos prominentes del paisaje. De esta manera, al proporcionar puntos de refugio alternativos en caso de ataque sorpresivo, aumentaban las posibilidades de

30. La zona de la montaña de Alicante presenta la mayor densidad de fortificaciones de todo el reino en el momento de producirse la conquista feudal. Según un censo realizado por J. Torró $(1998,386)$, existen aún hoy en día 108 fortificaciones entre Xàtiva y el término de Alicante, de las cuales unas 97, incluyendo torres de alquería, estarían en uso en el momento de la conquista, lo que da una densidad de un punto fortificado cada $38 \mathrm{~km}^{2}$.

31. Según J.Torró, el estado almohade carecía de los medios materiales y cohercitivos para emprender por su cuenta un programa constructivo de la magnitud del que observamos en la región y para asumir su posterior mantenimiento y plantea que, de haber existido alguna posibilidad de llevarlo a cabo es dudoso que sólo se centrase en reforzar defensivamente únicamente una zona tan concreta de sus dominios.

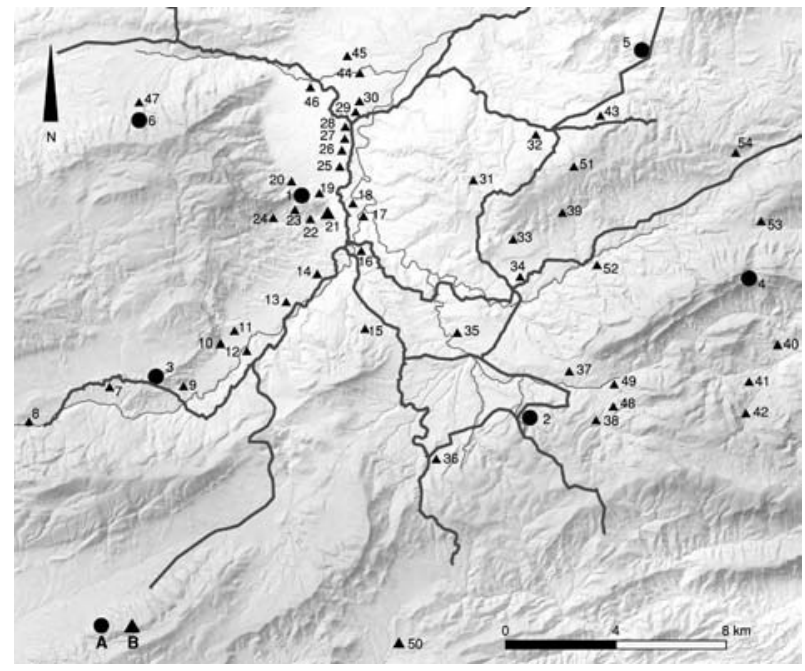

Figura 19: Asentamientos finales siglo XI- principios s.XII. A: Hiṣn . B: Qarya. A: 1: Castillo de Cocentaina. 2: Penàguila. 3: Castellar de Alcoy. 4: Pla de la Casa. 5: Margarida. 6: Agres. B: 7: Barxell. 8: Polop. 9: Torc. 10: Uixola. 11: Palomar. 12: Beniata. 13: Cotes. 14: Algar. 15: Penella. 16: Beniden. 17: Benifloret. 18: Camí del Puntarro. 19: Fraga. 20: Beniasmet. 21: Cocentaina. 22: Penyeta Blanca. 23: Atec. 24: El Raspall. 25: Alcúdia. 26: Benitaer. 27: Alcosser. 28: Rafol Blanc. 29: Benifit. 30: Benamer. 31: Benillup. 32: Almudaina. 33: Millena. 34: Gorga. 35: Benilloba. 36: Benifallim. 37: Benasau. 38: Alcoleja. 39: Balones. 40: Florent. 41: Confrides. 42: Alforfa. 43: Benialfaquí. 44: Cànoves. 45: Setla. 46: Muro. 47: Agres.48: Beniafé. 49: Ares. 50: Torre de les Maçanes. 51: Catamarruc. 52: Quatredondeta. 53: Fageca. 54: Benimassot.

supervivencia de la población campesina, librándola del cautiverio o la deportación.

A diferencia de las fortificaciones del s. XI, los castillos del s. XII son, ante todo, recintos pensados para responder eficazmente ante un ataque de gran intensidad acogiendo a un gran número de personas e incluso de animales. Es por ello que se sitúan más cerca de las zonas de producción, sobre espolones y elevaciones relativamente pequeñas o a media pendiente, ocupando grandes superficies ${ }^{32}$, con plantas en forma de plataforma elíptica, de pendiente suave o inexistente y, como ya dijimos, con soluciones defensivas más sofisticadas, detectándose incluso abundantes construcciones interiores, tales como: unidades de habitación, establos, hornos, almacenes y graneros ${ }^{33}$ (Torró, 1998, 401-402, 411).

32. Estas plataformas llaman la atención por la gran superficie que abarcan, generalmente por encima de los $1000 \mathrm{~m}^{2}$ y llegando a superar incluso la media hectárea.

33. Torró cree que normalmente no se trataría de residencias estables sino de alojamientos provisionales, considerando como excepcionales a los que claramente pueden ser identificados como poblados fortificados, pues el considera que esta forma de asentamiento no es compatible con la lógica de la sociedad segmentaria ya que constituye un impedimento para la dinámica doméstica de los linajes y la organización de las actividades campesinas. 


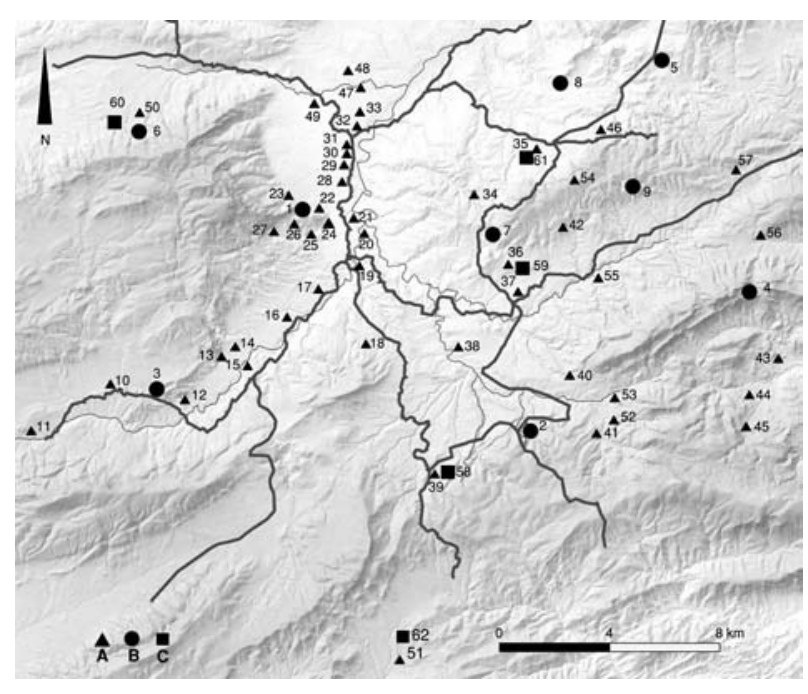

Figura 20: Asentamientos finales s. XII-principios s.XIII. A: Qarya . B: Hișn. C: Torre. A: 1: Cocentaina. 2: Penàguila. 3: Castellar de Alcoy. 4: Pla de la Casa. 5: Margarida. 6: Agres. 7: Travadell. 8: Planes. 9: Seta (o Costurera). B: 10: Barxell. 11: Polop. 12: Torc. 13: Uixola. 14: Palomar. 15: Beniata. 16: Cotes. 17: Algar. 18: Penella. 19: Beniden. 20: Benifloret. 21: Camí del Puntarro. 22: Fraga. 23: Beniasmet. 24: Cocentaina. 25: Penyeta Blanca. 26: Atec. 27: El Raspall. 28: Alcúdia. 29: Benitaer. 30: Alcosser. 31: Rafol Blanc. 32: Benifit. 33: Benamer. 34: Benillup. 35: Almudaina. 36: Millena. 37: Gorga. 38: Benilloba. 39: Benifallim. 40: Benasau. 41: Alcoleja. 42: Balones. 43: Florent. 44: Confrides. 45: Alforfra. 46: Benialfaquí. 47: Cànoves. 48: Setla. 49: Muro. 50: Agres. 51: Torre de les Maçanes. 52: Beniafé. 53: Ares. 54: Catamarruc. 55: Quatredondeta. 56: Fageca. 57: Benimassot. C: 58: Torre de Benifa1lim. 59: Torre de Millena (Billeneta). 60: Torre de Agres. 61: Torre de la Almudaina. 62: Torre de Torre de les Maçanes.

Sin embargo, la inminencia del ataque, la relativa lejanía de algunos castillos, la insuficiente capacidad de ciertas fortalezas o las necesidades específicas de defensa de algunas grandes alquerías determina la necesidad de contar con refugios complementarios y es con esta finalidad que se construye una densa red de torres de alquería.

Según Patrice Cressier (2004, 209-213), estas torres de alquería se diferenciaban de otras tipologías de torres de vigilancia de caminos o fronteras, por estar destinadas a la protección de bienes y personas, integrándose incluso al espacio de hábitat y disponiendo de zonas para el almacenaje de las reservas de la comunidad. Aunque se establecían preferentemente en las llanuras periurbanas de cultivo de regadío intensivo, como en la huerta de Valencia, ello no impide encontrar ejemplos en zonas montañosas asociadas a cultivos de secano. De cronología tardía (siglos XIII y $\mathrm{XIV}^{34}$ ) es la tipología a la que pertenecerían varias de

34. En nuestra zona, la construcción de estas torres de alquería abarca un arco cronológico más corto, que abarca desde el último tercio del siglo XII al primero del XIII, debido a que la conquista cristiana se completa antes que en otras regiones. las torres aisladas que podemos encontrar en nuestra zona de estudio, entre las que, según algunos autores, se encontraría la de Benifallim ${ }^{35}$.

En el espacio comarcal de los valles de Alcoy, la mayor concentración de las nuevas fortificaciones se ubicaba en el eje secundario norte-sur, acentuándose en los nudos entre esta vía de comunicación y las de acceso al valle desde comarcas vecinas: el Castell de Planes se situaba en el cruce con los caminos provenientes de Vall de Gallinera y Vall de Alcalà y, los castillos de Costurera y de Travadell controlando el ingreso desde la Vall de Seta. Apuntalando y complementando este sistema de vigilancia y protección, se hallaban las torres: la de Agres al castillo homónimo vigilando el ingreso desde el oeste a la Valleta de Agres, las de Almudaina y Millena a los castillos de Planes, Travadell y Seta y la de Benifallim al de Penàguila, controlando el puerto del Rontonar (Fig. 20).

A pesar de todos los esfuerzos puestos en el refuerzo de las estructuras defensivas, la conquista cristiana fue inevitable y entre 1232 y 1245 la mayor parte del Sharq Al-Andalus fue ocupado por las fuerzas catalano-aragonesas.

La implantación del feudalismo trae aparejados profundos cambios que se reflejan en un paisaje estructurado de manera absolutamente diferente. El sistema de hábitat disperso y aislado que caracterizaba a las alquerías es sustituido por un nuevo modelo representado por formas de poblamiento agrupado y fortificado. Las unidades de explotación andalusíes, organizadas en torno a un hiṣn, cuya área de influencia estaba delimitada por las condiciones naturales del relieve (Guichard, 1987 b 242) son reemplazadas por un número controlado de pueblas y villas (Torró e Ivars, 1989, 472) cuyos límites, claros y precisos, están reforzados por la fijación de los términos, fronteras internas cuyo trazado responde a consideraciones de tipo jurisdiccional. (Torró, 1990, 85). Los nuevos grupos humanos ya no están compuestos por familias extensas, comunidades

35. P. Guichard $(1982,30)$ sugiere un posible origen como torre de alquería del castillo de Benifallim, posteriormente aprovechada por los señores cristianos del lugar. J. Torró y P. Ferrer $(1996 b, 192)$ la identifican como tal: “...la relativa lejanía de los castillos respecto a muchas zonas habitadas y otros factores, como la necesidad de contar con graneros fortificados en puntos cercanos a las residencias, obligaron a complementar la red de castillos con las torres de alquería. Éstas se situaban, a veces, sobre una elevación inmediata, con pequeños patio contiguos, tal y como puede verse en Benifallim y Travadell.", aportando J. Torró (1998, 408) una nueva referencia al castillo en otro trabajo: “... Junto a los nuevos castillos, surgen masivamente las torres de alquería. Estos puntos defensivos menores, a escala de una o dos alquerías, estaban constituidos, esencialmente, por la torre propiamente dicha y un reducto o albacar contiguo. Podían situarse junto a la zona de residencia o sobre una elevación cercana, buscando una mayor seguridad. Entre estas últimas cabe mencionar las de Carrícola y Benifallim...” 
clánicas vinculadas por lazos de parentesco sino por familias estrictas de tipo nuclear, a las que se les asignaba una parcela urbana y un lote de parcelas rurales de extensión variable y composición diversificada, claramente concebidas para albergar y proporcionar sustento a un grupo doméstico limitado y que, a diferencia de la estabilidad de los territorios de las alquerías, estaban afectadas por una enorme movilidad mercantil derivada de la fragmentación de los patrimonios como consecuencia de los mecanismos de transmisión de las heredades ${ }^{36}$ (Torró, 1990, 60 y 83).

La estrategia de ubicación de las villas cristianas respondía a una necesidad de articular el territorio mediante el control de corredores y rutas interiores y la consolidación de las fronteras del reino (Torró, 1990, 75); no es casual entonces que, en los Valles de Alcoi, la zona de mayor densidad de población cristiana se ubique en la cuenca del río Serpis, área de concentración de los ámbitos agrarios más idóneos y donde discurre el trazado del principal eje de circulación y ruta alternativa de comunicación con las comarcas costeras de la zona de Alicante, a partir de las dificultades en el tránsito tradicional a través del Vinalopó, derivadas de los conflictos con el reino de Castilla.

La fundación de las villas de Cocentaina y Alcoi trae aparejada la desaparición de las alquerías cercanas, cuyas tierras se fraccionan y reparten entre los nuevos colonos, con los consiguientes problemas derivados de la adaptación forzada de los sistemas hidráulicos existentes, pensados para una gestión diferente de los espacios agrarios. (Torró, 1996, 204). Las nuevas formas de hábitat concentrado, resultado de la necesidad de favorecer el control de la fiscalidad y la defensa de las fronteras, justifican la construcción de los cierres amurallados de las villas, organizándose las zonas cultivables a modo de franjas en torno al perímetro de las ciudades, hasta una distancia máxima determinada por el alcance de los desplazamientos diarios que el campesino podía realizar para que dicha producción fuera rentable ${ }^{37}$ (Torró, 1990, 80-81).

Las explotaciones más alejadas, y que concentraban grandes extensiones territoriales, quedaban entonces en manos de latifundistas, que residían en las

36. Según J. Torró, $(1996,202)$ tanto la compra-venta como la herencia provocaban una enorme movilidad mercantil de la tierra, favorecida por el desinterés y/o las dificultades de las familias para ponerla en explotación, y la concentración en determinadas manos de grandes extensiones, desarrollándose en consecuencia procesos de estratificación de la comunidad colonizadora casi desde el momento de su constitución.

37. Las parcelas más cercanas a las murallas solían ser las huertas y, a continuación los campos de cereal y las viñas. Estos dos últimos cultivos cobran importancia en detrimento de las huertas ante la necesidad de poder almacenar y comercializar productos que no tuvieran una caducidad larga y de esta manera poder cumplir con las exigencias de las rentas señoriales (Torró, 1990, 83).

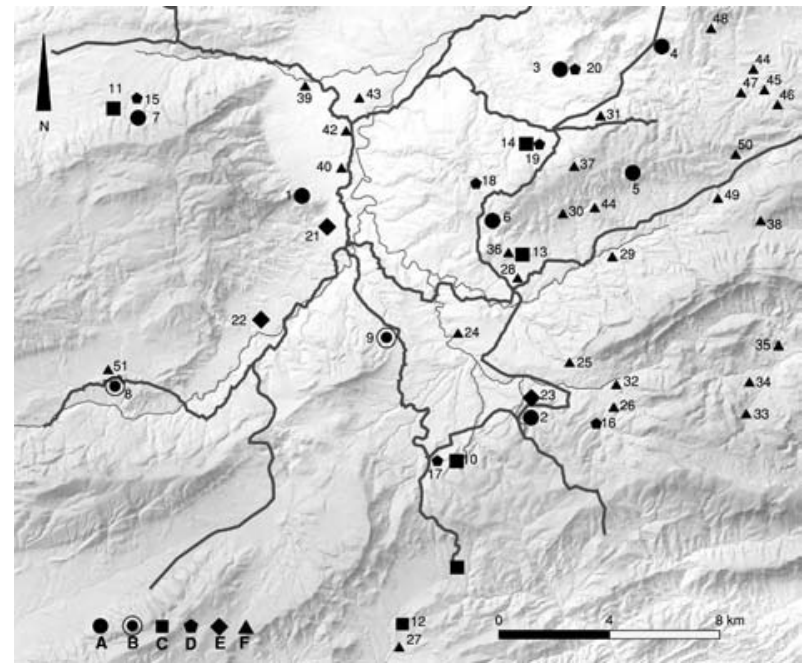

Figura 21: Asentamientos finales siglo XIII-mediados s.XIV. A: Castillo islámico conservado. B: Castillo de nueva construcción. C: Torre islámica conservada. D: Población cristiana menor. E: Villa cristiana amurallada. F: Poblado mudéjar. A: 1: Cocentaina. 2: Penàguila. 3: Planes. 4: Margarida. 5: Seta. 6: Travadell. 7: Agres. B: 8: Barxell. 9: Penella. 10: Benifallim. C: 11: Torre de Agres. 12: Torre de les Maçanes. 12: Torre de Millena. 14: Torre de la Almudaina. D: 15: Agres. 16: Alcoleja. 17: Benifallim. 18: Benillup. 19: Almudaina. 20: Planes. E: 21: Cocentaina. 22: Alcoy. 23: Penàguila. F: 24: Benilloba. 25: Benasau. 26: Beniafé. 27: Torre de les Maçanes. 28: Gorga. 29: Quatredondeta. 30: Balones. 31: Benialfaquí. 32: Ares. 33: A1forfa. 34: Confrides. 35: Florent. 36: Millena. 37: Catamarruc. 38: Fageca. 39: Benimassot. 40: Muro. 41: Alcudia. 42: Rafol Blanc. 43: Benamer. 44: Beniassó. 45: Benialí. 46: Benixarcos. 44: Capaimona. 48: Querola. 49: Roca. 50: Salema. 51: Solana. 52: Barxell.

ciudades y las trabajaban por medio de intermediarios, a veces colonos en régimen de enfiteusis pero, mayormente, mano de obra musulmana proveniente de otras zonas y realojada en las unidades de habitación que habían pertenecido a las alquerías. Estos traslados de población andalusí no eran casuales, sino que respondían a estrategias de descomposición de las otrora poderosas aljamas, a través de la disgregación de los grupos clánicos (Torró, 2006, 96-97) ${ }^{38}$. El grueso de la población indígena, será arrinconado en el oeste, en coincidencia con las zonas más montañosas y de menor productividad, generando una gran concentración de poblados en la Vall de Alcalà y la Vall de Seta.

A modo de límite entre las zonas predominantemente cristianas y las mayormente andalusíes, el eje secundario de comunicación norte-sur, será vigilado mediante la reutilización de las fortalezas anteriores a la conquista, la fundación de nuevas poblas cristianas: Planes, Gorga, Benifallim y Penàguila. Fuera de las

38. Un ejemplo de estas producciones latifundistas se dará en la zona de la alquería de Barxell, donde la construcción del nuevo castillo tendrá como finalidad controlar y proteger la zona, corredor de salida de los valles hacia la zona de Ibi, ahora explotada por población trasvasada. 


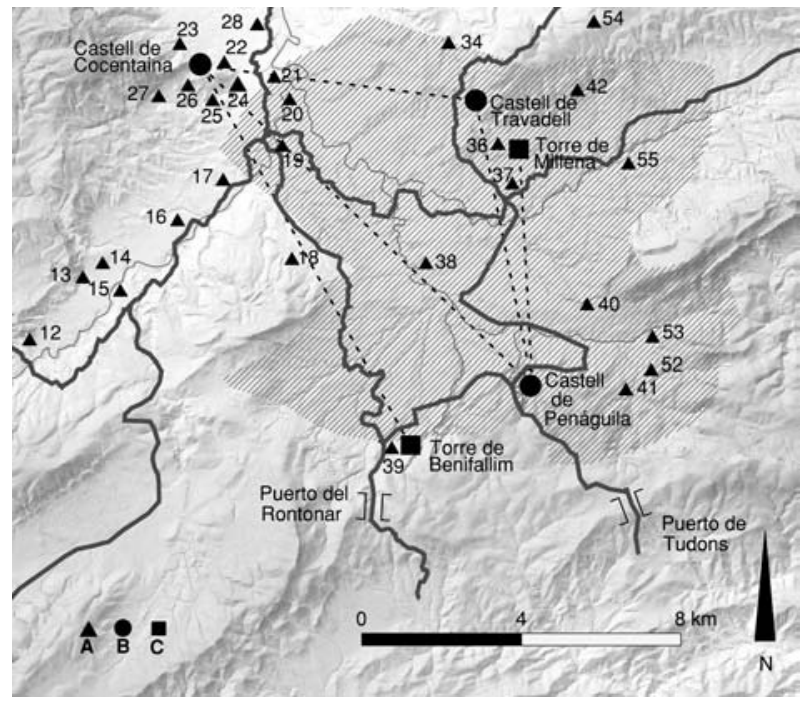

Figura 22: Benifallim en relación a las rutas, asentamientos y fortificaciones en época andalusí. El sombreado indica el dominio visual del Castell de Penàguila según I. Grau (2002: 198). A: Qarya . B: Hiișn. C: Torre A: 12: Torc. 13. Uixola. 14: Palomar. 15: Beniata. 16: Cotes. 17: Algar. 18: Penella. 19: Beniden. 20: Benifloret. 21: Camí del Puntarro. 22: Fraga. 23: Beniasmet. 24: Cocentaina. 25: Penyeta Blanca. 26: Atec. 27: El Raspall. 28: Alcúdia. 34: Benillup. 36: Millena. 37: Gorga. 38: Benilloba. 39: Benifallim. 40: Benasau. 41: Alcoleja. 42: Balones. 52: Beniafé. 53: Ares. 54: Catamarruc. 55: Quatretondeta.

redes castrales y ocupando posiciones periféricas en los intersticios de dicha red y ligados a localidades reconocidas como alquerías, como es el caso de Penella y Barxell, surge una nueva tipología de castillo, antecedente de los palacios-fortaleza señoriales, en los que todavía prevalecen las características defensivas sobre las residenciales.(Guichard, 1987c, 200-202). Torres, castillos y las pueblas de nueva fundación controlarán los accesos a la comarca y la circulación a lo largo de todas las vías de comunicación, protegiendo las zonas de mayor concentración de colonos ubicadas estratégicamente en las áreas más productivas ocupando el corazón mismo del espacio comarcal (Fig. 21).

¿Cuál fue el papel que desempeñó entonces el Castillo de Benifallim en estos esquemas de organización espacial que acabamos de analizar?

Benifallim nace como una alquería. Su implantación dentro de la Vall de Penàguila no es en lo absoluto aleatoria, además de la presencia de abundantes cursos de agua en las inmediaciones, se encuentra ubicado junto a una importante vía de comunicación y a un puerto de montaña que permitía el acceso a otras comarcas. Si bien carecemos de datos que nos permitan precisar su ubicación exacta, suponemos que no estaría muy alejada de la que ocupa la población actual ${ }^{39}$, pues

39. El reciente hallazgo de los posibles restos de un cementerio islámico en una zona ubicada al sur de la población conocida como el Freginal, refuerzan la hipótesis de esta continuidad entre ubicación de la qarya de Benifallim y la

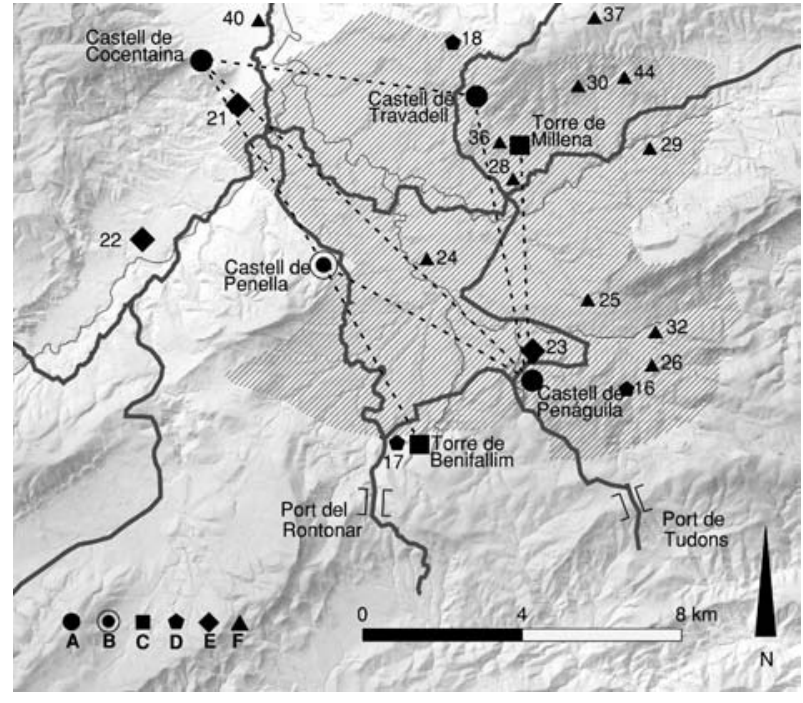

Figura 23: Benifallim en relación a las rutas, asentamientos y fortificaciones en época cristiana. .El sombreado indica el dominio visual del Castell de Penàguila según I. Grau (2002: 198). A: Castillo islámico conservado. B: Castillo de nueva construcción. C: Torre islámica conservada. D: Población cristiana menor. E: Villa cristiana amurallada. F: Poblado mudéjar. D: 16: Alcoleja. 17: Benifallim. 18: Benillup. E: 21: Cocentaina. 22: Alcoy. 23: Penàguila. F: 24: Benilloba. 25: Benasau. 26: Beniafé. 28: Gorga. 29: Quatredondeta. 30: Balones. 32: Ares. 36: Millena. 37: Catamarruc. 40: Muro.

la posición en la ladera, con un dominio visual amplio del valle y, sobre todo de, otros puntos fortificados, es de vital importancia debido a que el campo visual del castillo de Penàguila, el hișn a cuyo territorio estaba integrada, se halla limitada por las faldas de la sierra homónima, imposibilitando la visión hacia el sector meridional ${ }^{40}$, a excepción de un área limitada que abarca una parte del corredor del Port de Tudons. Este punto negro en el radio de alcances visuales del hișn, que no sólo dejaba desprotegido al asentamiento sino también al puerto de montaña del Rontonar, podría ser el detonante de la construcción de una torre en la alquería de Benifallim, cuya presencia complementaría el control y vigilancia y serviría para triangular información y avisos entre este sector limítrofe, el castillo de Cocentaina y el de Penàguila (Fig. 22).

En época cristiana, los castillos y fortificaciones estratégicamente viables son conservados y reutilizados, desmontándose sólo aquellos que no cumplían con este objetivo para evitar su reutilización por fuerzas enemigas. El asentamiento de los colonos en el valle del

actual localidad. (Ver ficha de registro de la Dirección general de Patrimonio de la Comunidad Valenciana, Yacimientos arqueológicos)

40. Grau trata en su tesis doctoral el tema de las visuales desde el castell de Penàguila exponiendo esta limitación de la cuenca visual hacia el sector meridional y que pude corroborar personalmente al subir a la peña. Las visuales abarcan un sector del corredor del Port de Tudons pero no a Benifallim. 
Serpis, ocupando las tierras más fértiles y fundando las villas de Cocentaina y Alcoi, transforma al eje secundario de circulación norte -sur en una especie de límite virtual entre las zonas cristianas y las de población mayormente andalusí, arrinconadas en las áreas más montañosas y marginales. Con la villa cristiana de Penàguila como cabecera, y a pesar de la fundación de nuevas pueblas, este sector de los Valles se caracterizará por estar ocupado, hasta la expulsión de los moriscos, por un importante número de población musulmana, hecho que sumado a la necesidad de un uso intensivo de los ejes de comunicación con las poblaciones mediterráneas, como vías de acceso alternativas del reino a ante las dificultades que afectaban a la ruta del Vinalopó, es determinante a la hora de fundar la villa de Benifallim y de conservar y/o reconstruir la torre, debido a la necesidad de establecer un control del camino y, sobre todo, del puerto de montaña, que el castillo de Penàguila, por los hechos anteriormente descriptos, se hallaba imposibilitado de ejercer (Fig. 23).

\section{CONCLUSIONES}

A pesar de haber sido denominado como castillo de Benifallim, no hemos encontrado características que nos permitan identificarlo como tal. La escasa superficie que ocupa el conjunto, el tamaño reducido de los elementos componentes (sobre todo del recinto), la aparente ausencia de estructuras adicionales que funcionaran como hábitat y sobre todo, las características de su implantación, nos permiten asociarlo a la tipología de torre de vigilancia y/o protección.

El estudio de la configuración de los paisajes históricos nos ha permitido detectar una serie de factores cuya combinación hacía imprescindible la presencia de la torre. La existencia de un núcleo poblacional, situado en relación directa con una vía de comunicación de relativa importancia y con un puerto de montaña, que enlaza el sistema de valles con el espacio extracomarcal, unido a la falta de visibilidad de este sector fronterizo desde los otros puestos fortificados, determinaron que fuera ésta su posición en el territorio, la más estratégica para defender y controlar su espacio de influencia.

Dentro de este esquema de organización territorial era altamente probable que pudiera tratarse de una torre de alquería, dada la situación de la qarya de Benifallim, ubicada posiblemente en un entorno inmediato al de la actual población. Sin embargo, este primer análisis arqueológico de su arquitectura arroja una datación más tardía, ubicando su construcción en el período inmediatamente posterior a la conquista cristiana. Las características de algunos elementos componentes, como el arco de acceso o la presencia de recursos defensivos, en concreto de saeteras, en el muro del recinto anexo, evidencian el carácter postislámico de la edificación, posiblemente erigida en el período de densificación de la red de asentamientos colonizadores que siguió al sofocamiento de las revueltas mudéjares, época en la que está datada la Carta Puebla de Benifallim.

Creemos, sin embargo, que es preciso ser cautos en nuestras conclusiones que deberán ser contrastadas en futuras intervenciones arqueológicas y complementadas con estudios documentales, que aporten datos más definitorios.

Mientras tanto, nos queda proponer una línea de trabajo complementaria centrada en el estudio sistemático de otros castillos de la comarca, para poder establecer líneas de coincidencia y aportar así más luz al estudio de estas pequeñas fortificaciones

Débora Marcela Kiss

dmkiss@hotmail.com

\section{BIBLIOGRAFÍA}

ACIÉN ALMANSA, M., 1995: "La fortificación en Al-Andalus", Archeología Medievale, 22, 7-36.

AYMAT ESCALADA, C., 2007: “Arquitectura de tierra: fábricas de adobe y tapial.", Apuntes del Master de Restauración y Rehabilitación del Patrimonio.Universidad de Alcalá de Henares, A2, 1-36,

AZKARATE, A. y GARCÍA, I., 2004: "Las casas torre bajomedievales. Análisis sistémico de un proceso de restructuración espacial/territorial", Arqueología de la Arquitectura, 3, 7-37.

AZUAR RUIZ, R., 1989: Denia Islámica. Arqueología y poblamiento., Alicante.

AZUAR RUIZ, R., 1991: Fortificaciones y castillos de Alicante, Alicante.

AZUAR RUIZ, R., 2005: Las técnicas constructivas en la formación de Al- Andalus. Arqueología de la arquitectura, 4, 149-160.

BARCELÓ TORRES, C., 1983: Toponímia aràbica del País Valencià. Alqueries i castells, València.

BAZZANA, A., CRESSIER, P. y GUICHARD, P., 1988: Les châteaux ruraux d'Al Andalus. Histoire et Archéologie des Husun du sud-est de l'Espagne, Madrid.

BLAY I MESEGUER, F. y SEGURA I MARTÍ, J. M., 1994: Guia Bibliogràfica de L'Alcoià - Comtat, Alcoi.

CABALLERO ZOREDA, L. y LATORRE GONZÁLEZMORO, P., 1995: "La importancia del análisis estratigráfico de las construcciones históricas en el debate sobre la restauración monumental", Informes de la Construcción, 46 n¹35, 5-18.

CRESSIER, P., 1991: “Agua, fortificaciones y poblamiento: El aporte de la arqueología a los estudios sobre el Sureste peninsular", Aragón en la Edad Media, 19, 403-428.

CRESSIER, P., 1999: "Château et terroirs irrigués dans la province d'Almería (X-XV siècles)”, Castrum 5, Colección Casa Velázquez n ${ }^{\circ} 55$.

CRESSIER, P., 2004: "Vigilar, proteger, habitar: a propósito de las torres en el ámbito rural andalusí", en P. MORET y T. CHAPA, Torres, atalayas y casas fortificadas. Explotación y control del territorio en Hispania, Jaen. 
CRIADO BOADO, F., 1999: Del Terreno al Espacio: Planteamientos y Perspectivas para la Arqueología del Paisaje, CAPA 6, Santiago de Compostela.

DE MIGUEL RODRÍGUEZ, J. L., 1998: "Muros", Restauración Arquitectónica, 1, 203-236.

FERRAGUD DOMINGO, C., 2003: El naixement d'una vila rural valenciana: Cocentaina, 1245-1304, Valencia

FERRANDO I FRANCÉS, A., 1998: Llibre del repartiment de Valencia, València.

DONOSO JIMÉNEZ, I., 2006: Habitat moris a la Muntanya d'Alacant. Etnografía histórica de l'espai morisc. Onda

FONT I MEZQUITA, F. e HIDALGO, P., 1991: El tapial. Una técnica constructiva milenaria. Colegio de Aparejadores de Castellón.

GARCÍA FITZ, F., 2005: Castilla y León frente al Islam, Sevilla

GRAU MIRA, I., 2000: El poblamiento de época ibérica en la región centro-meridional del País Valenciano, Alicante.

GRAU MIRA, I., 2002: La organización del territorio en el área central de la Contestania Ibérica, Alicante.

GRAU MIRA, I. y GARRIGÓS I ALBERT, I., 2007: "Aproximació al poblament romà de del Valls d'Alcoi", Recerques del Museu d'Alcoi, 16, 135-150.

GUAL CAMARENA, M., 1989: Las Cartas Puebla del Reino de Valencia, Valencia.

GUICHARD, P., 1976: Al-Andalus: estructura antropológica de una sociedad islámica en Occidente, Barcelona.

GUICHARD, P., 1982: "Los castillos musulmanes del norte de la provincia de Alicante", Anales de la Universidad de Alicante. Historia medieval, 1, 29-46.

GUICHARD, P., 1987a: "Geografía histórica e historia social de los hábitats rurales fortificados de la región valenciana", Estudios sobre historia medieval, 175-183, Valencia.

GUICHARD, P., 1987b: "Las comunidades rurales en el País Valenciano (siglos XI-XIV)", Estudios sobre historia medieval, 237-264, Valencia.

GUICHARD, P., 1987c: "Castillos cristianos del Reino de Valencia (siglos XIII -XIV)”, Estudios sobre historia medieval, 199-204, Valencia

GUICHARD, P., 2001a: "El apogeo del Islam andalusí (siglo X- inicios del siglo XIII)", en P. BONNASSIE, P. GUICHARD y C. GERBET, Las españas medievales, 85-127, Barcelona.

GUICHARD, P., 2001b: "Los campesinos de Al-Andalus (siglos XI-XIV)”, en P. BONNASSIE, P. GUICHARD y C. GERBET, Las españas medievales, 128-161, Barcelona.

GUICHARD, P., 2001c: "El nacimiento del Islam andalusí (siglo VIII- inicios del siglo X)", en P. BONNASSIE, P. GUICHARD y C. GERBET, Las españas medievales, Barcelona.

GUTIÉRREZ LLORET, S., 1992: El tránsito de la antigüedad tardía al mundo islámico en la Cora del Tudmir: cultura material y poblamiento paleoandalusí, Alicante.

LÓPEZ ELUM, P., 2002: Los castillos valencianos de la Edad Media., I y II, Valencia.

MAÑANA BARRAZÁS, P., BLANCA ROTEA, R. y AYÁN VILA, M., 2002: Arqueotectura I: Bases Teórico
Metodológicas para una Arqueología de la Arquitectura, TAPA 25, Santiago de Compostela.

MASQUERAY, E., 1983: Formation des cités chez les populations sédentaires de l'Algérie, Aix-en-Provence.

MOLINA HERNÁNDEZ, F., 2004: "La ocupación desde el Paleolítico medio hasta la Edad del Bronce en el área oriental de las comarcas de L'Alcoià y el Comtat (Alicante)", Archivo de Prehistoria Levantina, 25, 91-126.

NAVARRO POVEDA, C., 1990: Excavaciones arqueológicas en el castillo de La Mola. Las cerámicas comunes, II, Alicante.

RODRÍGUEZ NAVARRO, P., 2008: La torre observatorio en tierras valencianas. Tipología arquitectónica, Tesis Doctoral, Universidad de Valencia.

SALVADORI, M. y HELLER, R., 1987: Estructuras para arquitectos, Buenos Aires.

SEGURA MARTÍ, J. y TORRÓ ABAD, J., 1985: Torres $i$ Castells de l'Alcoià-Comtat, Alcoi.

TORRÓ I ABAD, J., 1990: Poblament i espai rural transformacions històriques, Valencia.

TORRÓ I ABAD, J., 1992: La formació d'un espai feudal: Alcoi de 1245 a 1305, Valencia.

TORRÓ I ABAD, J., 1996: "La conquista y colonización cristianas (I)", en M. SÁEZ, Historia de L'Alcoià, el Comtat y la Foia de Castalla, 193-203. Alicante.

TORRÓ I ABAD, J., 1998: "Fortificaciones en Yibal Balansiya. Una propuesta de secuencia", en Castillos y territorio en Al Andalus, Jornadas de Arqueología Medieval 1 (1996), 385-418, Berja.

TORRÓ I ABAD, J., 2006: El Naixement d'una colònia. Dominación i resistència a la frontera valenciana (12381276), Valencia.

TORRÓ I ABAD, J. y FERRER, P., 1996a: “La sociedad andalusí (I)", en M. SÁEZ, Historia de L'Alcoià, el Comtat y la Foia de Castalla, 169-180, Alicante.

TORRÓ I ABAD, J. y FERRER, P., 1996b: "La sociedad andalusí (II)", en M. SAEZ, Historia de L'Alcoià, el Comtat y la Foia de Castalla, 181-192, Alicante.

TORRÓ I ABAD, J. e IVARS, J., 1989: "Villas fortificadas y repoblación en el sur del País Valenciano. Los casos de Cocentaina, Alcoi y Penàguila", III Congreso de Arqueología Medieval Española, 472-482, Oviedo.

TORRÓ I ABAD, J. y SEGURA I MARTÍ, J. M., 1991: "Asentamientos cristianos fortificados (siglos XIIIXIV): una aproximación tipológica para el sur del País Valenciano", Fortificaciones y Castillos de Alicante, 147-181, Alicante.

VALDÉS FERNÁNDEZ, F., 1992: "La arquitectura militar en Al-Andalus", Actas del IV curso de cultura medieval. La fortificación en la península ibérica, 123-136, Aguilar de Campoo.

VARELA AGÜI, R., 2002: La fortaleza medieval: simbolismo y poder en la Edad Media, Valladolid.

RECURSOS ELECTRÓNICOS.

Centro Nacional de Prevención de desastres. Coordinación General de Protección Civil.México.l. Preguntas frecuentes sobre sismos. [ en línea] disponible en http:// www.cenapred.gob.mx/es/PreguntasFrecuentes/faqpopo3.html\#preg2 [ consulta: 15 de septiembre de 2011]. 